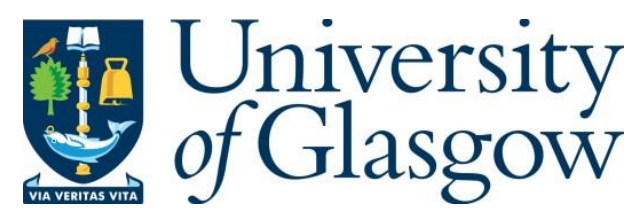

Wilson, J. M. (2018) Deconstructing the re-invention of operations management. Journal of Management History, 24(2), pp. 128-155.

There may be differences between this version and the published version. You are advised to consult the publisher's version if you wish to cite from it.

http://eprints.gla.ac.uk/155374/

Deposited on: 15 January 2018

Enlighten - Research publications by members of the University of Glasgow

http://eprints.gla.ac.uk 


\section{Deconstructing the Re-invention of Operations Management}

\section{Introduction: The Operations Management "Narrative"}

One feature of postmodernism is a questioning of "grand narrative": the story used by a discipline to make sense of itself and its place; these may be explicitly expressed and recognized, or unstated and implicit (Lyotard, 1979). Cummings (2002: 9) asserts that the development of management is "contingent rather than fundamental" and this perspective enables critical thinking and the questioning of conventions. The contingencies that have shaped the discipline of Operations Management, an “episteme” from a Foucauldian (Foucault, 1969) perspective, should be recognized and their effects understood, for such understanding directs attention not only toward issues; but equally significant, away from others. These contingencies and different foci are seen in the reinvention of Operations Management in the 1960s. That is, Operations Management as a discipline is a social construct and a "...systematic analysis of the factors that lead events or objects to be retained or lost as part of the stream of collective memory." (Swindler and Arditi, 1994: 309) This paper will deconstruct its development, analysing and critiquing the literature that defines and directs the discipline; recognizing how those have changed, and appreciating the underlying forces that have influenced them. Rather than considering the discipline as having advanced linearly we will assume a post-modernist perspective (Foucault, 1969) considering its "progress" to have been irregular, even discontinuous; and affected by interactions with other disciplines in the past and present, and both emasbled and contested by practicing managers.

Deconstruction (Ricœur, 1983; quoted by Kharbi, 2009: 372) is used for uncovering the questions behind the answers provided in the currently recognized foundational texts of 
Operations Management. Our objective is to develop an intellectual history of the discipline and the ideas that have shaped it; and analyze its relationships with the closely related disciplines of Operations Research/Management Science and Industrial Engineering (or Production Engineering in the UK). Explicitly recognizing the varied factors that first enabled the discipline's rise; then contributed to its difficult contested times, and ultimately lead on to its reemergence may permit a more considered approach to its future development. This study will consider the post-war developments in the field, with a specific deconstruction of its professionalization after the 1960s. We will offer a perspective on its future, within our consideration of its past and current position amongst allied disciplines. This provides an intellectual history of the ideas that have formed and comprise the discipline, and an examination of the "ecology" of the professions within which it exists.

\section{Production Modes \& Management-A Summary Hiostory}

Figure 1 provides an overview of the historic development of production modes and management, from early times until the present. This modifies Wilson's (1995) evolutionary perspective that viewed these developments as progressing from basic, undifferentiated production methods with little known management to increasingly complex production modes and system having specialized management ideas and techniques. Plato's Republic (Bloom, 1968) first noted specialization with the differentiation between occupations (farmers, soldiers, weavers, merchants, etc.) that Adam Smith (1776) later refined and evaluated at the level of the production processes involved in making pins. The Figure imposes a modern conceptualization of production modes that range from: First, projects that involve unique, usually large scale civil engineering works in ancient and earlier times, to Second, small scale production of batches of similar items, with possible differentiation between batches. Then Third, modes with larger scale 
or mass production of standardized items and; Finally, in the continuous or regular production of identical products, as with paper, cloth, iron, etc. Paralleling these developments in differentiating production modes were ideas about management. A key insight is that these distinct production systems arose before management thinking, analysis and theorization about them: theorization follows practice.

\section{Insert Figure 1 Here}

Unique projects like the Pyramids, irrigation systems, and others existed from ancient times (Kozak-Holland, 2011), although little was said about their management until Defoe's Essay (1697) with no formal technique described before Gantt's Charts (1903)_although those were not specifically applied to projects until the 1930s. (Clark, 1925 ignores them; Wilson, 2003).

At the other extreme, with generic production using processes; these also became differentiated early. Mills of various types appeared in medieval times for making cloth, sawing wood, etc. (Gimpel, 2007; Hills, 1993; Lucas, 2006; Major, 2008) and specialized processes and faciltiies for smelting metal. The most significant modernization of Mills could be seen with Evan's Guide (1795) in which a flour mill was fully mechanized with transfer lines, storage buffers and various processes supporting the milling activities, with the objective of allowing labor savings and improved, consistent quality. Mayr (1970) discusses the evolution of automatic control systems through the $1800 \mathrm{~s}$ - processing facilities became increasingly mechanized with control and feedback systems eliminating labor and improving the consisyency of their operations.

On the continuum of production modes, from single unit (projects) to generic (process) production it is notable that these extremes were the first to differentiate and have discussions of 
their "management" issues. After 1800, with Eli Whitney's efforts at standardization, manufacturing started to evolve from making single, handcrafted production into small batch and larger scale production. The development of batch production modes is well described by Hounshell (1984), particularly in the American System of Manufacture (Rosenberg, 1969) that Hounshell (1984) sees eventually leading to Ford's implementation of the assembly line and mass production. However, production lines have a deeper history, with the Venice Arsenale's assembly of galleys in 1574 (Davis, 2007) and Bentham and Brunel's Portsmouth Block Mill (Cooper, 1981-2, 1984) using them for the mass production of blocks in 1808. These early examples had limited effect, and it was only in the 1900s that such approaches became widespread, with supporting management commentary and theorization.

Although Charles Babbage (1832) and Andrew Ure $(1835,1840)$ discuss manufacturing in broad terms they did not discuss its management per se, offering only broad perspectives and occasional, more specific anecdotes (Babbage, 1832, §332) concerning management. Perhaps the most significant organization promoting management thinking in the 1800s was the American Society of Mechanical Engineers (ASME), with Towne (1886) and numerous other contributors to its Transactions from then through the 1920s. (Merrick, 1984) Those developments lead to Taylor's Shop Management and scientific management in the early 1900s. At that point, management might be said to have become established alongside contributions from Weber on bureaucracy (Mitzman, 1970) and Fayol's (1930) interests in administration and management control. In the 1920s the ASME's developments provided the foundations for the disciplines of Industrial (or production) Engineering, for Management Accounting, and for Production and Operations Management. Figure 1 summarizes these developments in manufacturing modes with their parallel but loosely related management commentaries in the right column. The disciplines 
of Industrial Engineering and Management accounting have continued their distinct development.

Until the 1950s Scientific Management was almost synonymous with Production and Operations Management (POM). Taylor's Shop Management (1903, 1911) laid POM's foundation as a well-defined management role; consolidating and rationalizing $19^{\text {th }}$ Century thinking about production management. (Copley, 1923) But POM in the early 1960s faced existential threats from demands for greater professionalization and from a newer, even more "scientific" discipline: Management Science. This threat arose from several factors working together: First, Management Science and Operations Research (OR) methods developed during and immediately after the Second World War provided a powerful intellectual framework for analysing and solving problems - ones that were previously the province of POM. Operations researchers came to many of the problems OM considered their own, but armed with powerful quantitative tools. Indeed, it seems impossible (Fuller and Mansour, 2003; Voss, 1984) to separate completely the two as distinct disciplines given their mutual interests. Gieryn (1983: 785) would see the "boundaries" between the two disciplines as blurred; and yet to be resolved if they can be demarked at all. Abbott, (1988) describes a system of professions in which each must continually defend their privileged status against other groups, and the shared interests and expertise between OM and OR reveals their complementarity and competition. Lyotard (1979: 52) observes that the encroachment of one discipline on another leads to confusion, and potentially "de-legimitization" of the old.

The British origins of operational research during World War Two also provided a developmental locus within British industry that had been less receptive to Taylorism and Fordism than in America (Cadbury, 1914; Garside and Greaves, 1997; Jenkins, 2011; Lazonick, 
1981; Lewchuck, 1984, 1985; Rae, 1960; Ritchie, 1997; Rowlinson, Michael, 1988; Smith and Boyns, 2005; Tiratsoo and Tomlinson, 1993, 1997; Tolliday and Zeitlin, 1991; Whitston, 1995, 1996, 2015; Woollard, 1925, 1954) and; perhaps, more open to such innovation in problem recognition and solving. British Industry found some features of Taylorism inappropriate, and already possessed a long history of production management, with the Institution of Production Engineers established in the 1930 following a long gestation periods as an informal organization. More specialized British organizations concerned with mining, railways (Edwards, 2010, 2011) and canals had also been established. Both British industry and academia (Tiratsoo, 2004; Tiratsoo, Edwards, and Wilson, 2003) were discriminating in their acceptance of American developments, reflecting national differences. Rosenhead (2009) provides an overview of how the American focus on technique arose and became dominant while Denizel, Usdiken and Tuncalp (2003) observe that the American dominance in OR journals has weakened, with contributions from elsewhere in the world moving closer to the more applications-oriented British approach. Given these differences our focus will concentrate on American developments, for it is there that these disciplines were most differentiated, and most in conflict.

Second, advances in computing (Cortada, 2003; Ranyard, 1988) enabled OR's computationally intense approaches to be implemented effectively. Third, these developments serendipitously coincided with increases in the teaching of business subjects in Universities so they reached a broader audience, including many practitioners. A fourth development was the increasing differentiation between the engineering aspects of the discipline (engineering economics, ergonomics, job design, work-study, etc.) and its management dimensions was evinced by the founding of the American Institute of Industrial Engineers in 1948. (Emerson and Naehring, 1988; Emiliani and Seymour, 2011; Woolard, 1925, 1954) The American Society of 
Mechanical Engineers provided an outlet for Taylor, Alford and many other pioneers in developing engineering management and encouraged its emergence as a discipline with academic programs starting as early as 1909 in Pennsylvania and 1933 at Cornell. (Emerson and Naehring, 1988)

Finally, and most significantly, in the 1950s American Universities started emphasizing the need for academic rigor within the management disciplines generally. Naylor (2012) describes a "business school coup d'état" in which scientific rigor became dominant following the Pierson (1959) and Gordon and Howell (1959) reports and subsequent Ford Foundation efforts to upgrade management education. McFarland (1960) calls it a revolution. Goodrick (2002) describes this as a "paradigm shift" in which radical changes affected business schools generally. One of the most heavily criticised disciplines in those reports was production and operations management, so it was vulnerable to encroachments of a more "scientific" discipline. Management Science apparently offered everything needed to address the desire for making management education more rigorous. Academic operations management was in mortal danger. Its response was to redefine and refocus - an emergent strategy only apparent in hindsight, a reinvention that constructed a discipline distinct from its new competitor, and worthwhile in and of itself. This differentiation is central for establishing a viable discipline. (Abbot, 1994)

\section{Redefined, Refocused, Reconnected and Revived}

Elwood Buffa $(1961,1965$, and 1969) is particularly recognized for having a central role in redefining "modern" production and operations management. Singhal, Singhal and Starr (2007) and Sprague (2007) highlight his impact. In "delineating" (Singhal, et al.) the discipline Buffa implicitly set boundaries identifying topics and issues for POM. This is notable on two fronts: first, it explicitly included OR methods, co-opting these techniques as tools rather than 
abandoning applications to a new, competing discipline; arguably, subordinating and dominating it. Secondly, Buffa's text excluded many topics present in earlier texts, narrowing the discipline's focus and more clearly aligning the discipline with managerial issues. That narrowing of the discipline was a de facto concession to the competing discipline of Industrial Engineering - no longer would business-oriented managers consider such predominantly engineering issues (work-study, ergonomics, etc.) within their realm of expertise. Others contributed, too, as recognized by Meredith, Amoako-Gyampah (1990); Singhal and Singhal (2007), Skinner (1985, 2007); Bayraktar, Jothishankar, Totoglu and Wu (2007) so that the synthesis they and Buffa's textbooks provided has been the dominant consensus about the discipline's concerns ever since. It should also be noted that the redefinition also gradually shed "production" from its public face-instead emphasizing its broader focus on Operations Management (OM). His renaming took POM off the shop-floor and into the executive suite, and into the growing area of services as well.

The disciplinary "niche" occupied by OM was thus defended, but that redefinition was not the only response. Skinner $(1969,2007)$ complemented and extended Buffa's managerial focus by differentiating OM through emphasizing strategic issues, thereby establishing a managerial presence that OR (Ackoff, 1979; Kirby, 2003b; Sodhi and Tang, 2008) has not been able to emulate. The perspectives provided by Buffa and Skinner have continued to mould the discipline's understanding of itself: defining its interests and shaping its research agenda as may be seen in Meredith, Raturi, Amoako-Gyampah and Kaplan (1989); Neely (1993); Pannirselvam, Ferguson, Ash and Siferd (1999); Craighead and Meredith (2008); Fry and Donohue (2013). These all show strategic issues as highly visible, long standing concerns within the POM literature, with OR relegated to being a means for achieving operational goals. These are 
significant issues and remain important, but only as operational tools deployed to achieve strategic goals.

That is, many OR techniques consider optimizing low-level production activities. For example, Salveson (1955a, 1955b) develops an optimization technique for assembly line balancing 40 years after Ford (1924) first implemented those systems. Wilson (2014) critiques subsequent developments as being too limited, with a focus only on optimization of the line itself without consideration of its role within the larger organization; in OR terms this pursued "local" optimization to the detriment of the whole organization. Similarly, Gantt (1903) initially consider the "machine loading" problem with his charts intended to manage factory-level operations (Clark, 1922) A narrower focus on the problem was taken with the derivation of Johnson's Rule, first meant to optimize loadings on a single machine, then generalized to a series of machines. (Johnson, 1954; Hall and Magazine, 2003) Earlier developments in inventory management (Harris, 1915, Erlenkotter, 1990; Gilbert and Schonberger, 1983) were embraced by OR although they had been virtually ignored previously. These OR developments in batch and mass production were matched by further formalization of project management with the Critical Path Method (Kelley and Walker, 1989, Peterson, 1991) in the mid-1950s, and the proliferation of optimization applications in managing processing plants, particularly for refinery operations. (Garvin, Crandall, John. and Spellman, 1957.) Operations research derived techniques were very powerful tools for managing well-defined and specific problems, although those tended not to be strategic, or broad in their nature. Rigorous analysis was then applied to other earlier operations problems: queuing (Kleinrock, 1975) and quality control (Juran, 1995) as distinct from quality management, as well. OM was under a heavy, and broad-based assault from the newer discipline that seemed able to provide better and more thorough analyses and solutions to the discipline's 
interests. But, OR was a victim of its own success: very good at local optimization, but disinterested in the larger systems within which it functioned.

Skinner (1973) describes OM as having survived "seven lean years" and even “...narrowly escaped extinction...." remarking that it was not then entirely safe, and only after another several years did the discipline become confident of its future. The field's defensiveness during the 1970s is revealed by Andrew and Johnson's (1982) assertion that OM is "crucial", Voss's (1984) identification of it as a "key discipline" and area for research, while Chase and Prentice (1987) speak of "a field rediscovered." The establishment in 1980 of the Journal of Operations Management and the International Journal of Operations and Production Management both dedicated to the field marked a new epoch and the discipline's increased confidence.

The OR threat to $\mathrm{OM}$ is ironic. Business Schools greatly benefited from co-opting Scientific Management before and after the First World War. (Schachter, 2010) Taylor and his foremost promoter C. Bertrand Thompson (Thompson, 1914, 1917) both taught at the Harvard Business School, Dartmouth also favoured scientific management and Dexter Kimball of Cornell was an advocate. Thorstein Veblen (Schachter, 2010) and many others then criticised the idea of teaching management for being "vocational." Mulligan (1987) observes these cultural divides remain, the establishment of the Said Business School at Oxford University was criticised on this point by staff from more traditional disciplines. (Anonymous, 1997) Taylor's Scientific Management offered a well-founded, comprehensive alternative to earlier approaches that would quiet the critics. Scientific Management legitimized Business Schools by bringing a rigor and comprehensiveness to the discipline of OM in particular. Taylor's system was eminently practical, intended for practitioners; but it also contained a thorough analysis of factory 
operations that allowed Universities to accept it. Business Schools in the 1960s looked on Management Science exactly as they had regarded Scientific Management fifty years before: it helped legitimize their existence.

\section{Scientific Management Dominant}

In practice, Taylor's Planning Office and system of functional foremen became the norm (Alford and Bangs, 1945; Drucker, 1955) from the 1910s through the 1950s: texts on OM conformed to Taylor's system. A review (Wilson, 2011b) of OM books from the 1940s through the mid-1950s shows Taylorism was the dominant doctrine, with its system for organizing and managing operations ubiquitous. Drucker (1955) recognizes the importance of Scientific Management, calling it the most important American contribution to world civilization since the Federalist Papers. It is perverse that OM does not more fully embrace Taylor's $(1903,1911)$ Shop Management. Drucker (1955) also observes that Scientific Management had been stagnant for many years, but implicitly undervalued its practical achievements and on-going dominance of manufacturing practice and thinking. American industry responded well to the demands of World War Two producing enormous quantities of goods, and then shifted to producing domestic products when the war ended. In addition, Scientific Management had been subjected to decades of criticism so severe that it remains discredited even today. Simha and Lemak (2010) provide an overview of its popular perception and argue that exposure to Taylor's own work rather than second-hand critiques are a corrective. Boddewyn (1961), Nyland (1987), Kanigel (1997), Guillén (1997) and Wagner-Tsukamoto (2008) all argue Taylor should be evaluated within the context of his time, and recognized for his progressive views. Taylor's Shop Management (1904) is seldom cited relative to his Scientific Management (1911), yet it is arguably the more important and significant contributor to the discipline, as will be shown later. 
The repositioning of OM lead to downplaying earlier involvements considered most "vocational" or Industrial Engineering oriented. Those tended to be associated with Scientific Management: work study, time-and-motion analysis, shop-floor management, etc. By the 1970s Scientific Management had been virtually banished from OM. Given its pervasive negative image, its intellectual stagnation and perceived vocational orientation; it was quite easily jettisoned as a theme within OM's modern incarnation. The idea (Gould and Eldredge, 1977) of a "punctuated equilibrium" is apt: one intellectually dominant perspective was replaced very quickly by a different one better suited to a newly changed environment. The rise and prospective dominance of Management Science during the 1950s and 1960s strongly affected OM, and we may see Management Science displacing Scientific Management within OM. In effect, OM adapted by adopting many of the methods used in OR. Fuller and Mansour (2003), Voss (1984) and others note the overlap between the techniques used within the two disciplines.

\section{"Modern" Operations Management and Modernity}

Operations management may have become "modern" in the 1960s but much was old. The Scientific Management era provided: economic order quantities, queuing theory, assembly lines, statistical quality control, and Gantt Charts. (Sprague, 2007) With so many of the techniques still used in OM originating with Scientific Management it is impossible to argue that the 1960s represent a clean break with earlier practice. It could be further argued that Taylor's management philosophy was, and remains so pervasive (Braverman, 1974; Kanigel, 1997) that it continues influencing OM practitioners and academics. OM does not need to acknowledge its Scientific Management antecedents to feel their effects.

Operations Management should never-the-less be considered the pre-eminent "modern" management discipline precisely because of its origins with Taylor and Ford: the commencement 
of Modernity was recognized by Virginia Wolff's (1924) observation that "On or around December, 1910, human character changed." notably coinciding with the first use of the term "Scientific Management" in the Eastern Rate Case raising Frederick W. Taylor to wider prominence (Copley, 1923), and also with Ford's completion of their state-of-the-art modern Highland Park Factory. (Ford, 1924) Operations management was, is, and continues to be resolutely "modern" in its conviction of its ability to understand, control and manipulate an organization's operations. The discipline is thoroughly positivist, believing the world can be studied, understood, and known; and then manipulated, and that neutral positions may be exploited to yield objective knowledge on which "progress" can then be built. Articles in research-oriented OM journals reveal a hypermodernity ${ }^{1}$ characterized by a "...diminution or outright repudiation of the past, since yesterday's knowledge can be considered 'less' than today's." (Anonymous, 2012) Although post-modernism has made an impact in some management disciplines it remains rare within OM. Few articles on post-modern operations have been published in comparison with the other management disciplines, OM has yet to transcend its modernity_and, seemingly, has no interest in so doing.

\section{The Operations Management "Narrative"}

In questioning OM's "grand narratives" one striking issue is the relative absence of Scientific Management. Our deconstruction of OM's dominant narrative will have as one objective to simply recover its earlier narrative: the pre-1960s historical literature and understanding of Scientific Management's role and contributions that OM ignores now; and, perhaps, overcome OM's antipathy towards its own history. Piercy (2012) observes that the

\footnotetext{
${ }^{1}$ Hypermodernity as defined by Wikipedia, itself a hypermodern mode of knowledge management and exchange that may in the future become academically respectable even for journals such as this one as its citation here self-consciously intends, differentiated from more traditional sources that might have been used instead.
} 
discipline lacks even an "implicit” interest in its history, echoing Wilson's (1995b) comment that the discipline was ignorant of its own history. Piercy (2012), McKay (2003) and Wilson (1995b) all surveyed introductory texts in the field and found few contained more than a few mentions of historical developments. This seems more systematic than the organizational forgetting of workflow innovators observed by Sayles and Stewart (1995) and more extreme than the general tendency in management as noted by Cummings (2002). Thus, OM is largely rootless with its “deep" history not only unknown and unacknowledged, but subjected to a conscious disinterest.

Nevertheless, many significant developments in OM since the 1970s have been reaffirmations of older ideas and methods embodied in Scientific Management. Buffa (1980) argued that the previous incarnation of the discipline was based on texts dominated by Industrial Engineering and otherwise purely "descriptive" treatments of operational issues, lacking in intellectual rigor and analysis. The 1960s revolution cut the discipline from its roots; wrongly, since it can be shown that many later developments draw upon Taylor's work or other old practices.

\section{Abstraction and Academification vs Reality and Practice}

The impression is that "modernized" equates with becoming more "scientific" and "rigorous", theory-based. To exaggerate the case: before modernization there were rough-andready theories and techniques derived from lived experience by real production managers in real factories, proven in practical use. Then afterwards, there were University Professors ${ }^{2}$ hypothesizing theoretical constructs of an abstracted reality; excruciatingly expressed

\footnotetext{
${ }^{2}$ The author is a prime example of such an academic: A tweed jacketed [personal identification removed] housed in one of the [personal identification removed] universities loath of any involvement in real-world enterprise, and who has himself contributed a few esoteric EOQ model variants to respectable OM and OR journals.
} 
mathematically (particularly in OR), analyzed and optimized; with the results written up in arcane jargon to be published in obscure, low circulation journals and read, if at all, by others of their ilk. All this done while working isolated in ivory towers separate from "the real world". However, this view is; or, at least, it has been; very wrong for OM: academia and practitioners are deeply engaged in a symbiotic relationship, legitimizing each other and mutually beneficial.

Lummus (2007) describes the role of the American Production and Inventory Control Society (APICS) in professionalizing the discipline during the 1960s and 1970s, with its journal, Production \& Inventory Management often the only outlet for academic work judged inappropriate by OR journals. The author notes that when undertaking his own post-graduate OM studies in the late 1970 s and early 1980 s that $P \& I M$ and other APICS publications were critical resources, but none of those are now considered worthy by reviews of the post-1980 research outlets described above. The increasing academification of OM and these trends in research journals reflect the "natural drift" that Corbett and van Wassenhove (1993) thought helped marginalize OR. But this "drift" seems less of a threat to OM due to its greater engagement with practitioners and openness to industrial developments, Lummus (2007: 343) notes the on-going involvement of Academics in the practitioners' organization APICS. There seems to be nothing similar in OR. From a sociological perspective (Swindler and Arditi, 1994) Academics may hold a "privileged" status in its construction, but that is a "contested reality" in which practitioners have been, and will continue to be, active participants and co-creators. The dynamics of these interactions are more accessible for OM practitioners when the more practical aspects of the discipline are addressed than when the more esoteric aspects of OR theory are concerned. 
The major OM journals such as the Journal of Operations Management, Production \& Operartions Management, the International Journal of Operations \& Production Management and the International Journal of Production Research all assert that the "ideal manuscript balances rigor with relevance" (JOM, 2017) One even tells prospective authors: "Work that is purely algorithmic in nature ... is likely to be more suitable to a journal in the management sciences or operational research.” (IJOPM, 2017) quite explicitly relegating OR to the category of a tool to be used. The IJPR (2017) has a more engineerting orientation, but its policy too favors “...major advances in theory, as long as their main concepts and usefulness are clearly explained...." Although these journals all assert their interests in maintaining engagement with industry and practitioners, and require authors to demonstrate relevance they nevertheless may display degrees of professional "regression" (Abbott, 1988) in which more theoretical contributions are priviledged. The journals' goals may be subverted through the reviewing process: reviewers may judge submissions prejudicially favouring those with stronger theoretical aspects and methodologies over those emphasizing practical applications. The balance between theory and practice is thus socially constructed with professional and journal status weighing in the scales.

Nevertheless, since the 1970s the impact of materials requirements planning (MRP), Japanese manufacturing ideas, quality management, business process re-engineering, supply chain thinking, services as operations, and others have continued to refresh OM by providing new issues and problems to engage its interests; and all of those have originated in industry rather than academia. In their retrospective, Chopra, et al. (2004: 9) opine that in the 1970s “...the ascendancy of the Toyota production system ... suggested the locus of creativity had shifted away from academia." OM continues to be re-vitalized by industry in ways that 
seemingly elude OR. Chase and Prentis (1987: 361) assert that OM more than any other management discipline draws its "...research thrusts from the real world." and Bayraktar, Jothishankar, Totoglu and $\mathrm{Wu}(2007: 865)$ maintain that "OM needs to continually monitor its research base against industrial realities." In contrast, Corbett and van Wassenhove (1993) observe OR becoming increasingly isolated with "self-referential" research, academics engaging only with other academics.

The mechanisms for reintroducing Scientific Management ideas to OM academics are the practitioners, who were insulated from the pressures on academics to be rigorous, and who positively regard practical, but academically disreputable "vocational" aspects. The most significant of these developments was the industrial crusade supporting MRP, an effort during the 1960s and 1970s that also sustained the OM discipline throughout the critical period when it was struggling to survive. Operations Management was not just redefined and refocused by its academics, but also reconnected with its practitioners having a major industrial development benefiting academic involvement and research agenda. MRP was a direct descendent of Taylor's Shop Management system: a modern implementation of Taylor's Planning Office. (Wilson, 2011b, 2012)

\section{The Planning Office Then and MRP Now vs EOQs}

Operations Research promoted EOQ theory and its use, having a major impact on inventory management in the 1950s and 1960s. Although EOQs originated coincidentally with Scientific Management they were not widely embraced then. Elbourne (1918) observed that attempting to optimize lot sizes within a factory was impractical. Orlicky (1975: ix) pointedly observed: "Materials requirements planning has become a new way of life in production and inventory management, displacing older methods in general and statistical inventory control in 
particular...." [Emphasis added] The profound incompatibilities between MRP theory and practice in dependent demand production environments and EOQ models best suited to independent demand applications created a situation where OM practitioners implemented systems independent of OR theory.

Mabert (2007) traced the development of Materials Requirements Planning to the postWar period and asserts that 1940s production planning systems used "the general logic" of MRP systems. This point can be strengthened: best practice in 1940 s production planning systems used exactly the same logic as later MRP systems. Skinner (1985: 79) maintains that these early systems were "....in effect a computerless form of MRP... with the calculations done by the business machines of the 1920s and 1930s." Taylor's Planning Office provided the foundations for those mid-century systems.

Wilson (2015) traces the evolution of Taylor's system of functional foremanship by considering the functions performed: master scheduling, inventory control, production planning, shop floor control, etc. These functions were initially done using manual information handling and processing methods. Those then provided the individual applications for electro-mechanical "accounting machine" based sub-systems starting in the 1920s that were slowly integrated, culminating with fully integrated systems in the late 1940s. The theoretical and practical foundations for digital implementations that culminated in MRP in the 1960s lay within those earlier systems. Orlicky (1975: 6) observed that the chief obstacle to implementing MRP before the 1960s had been insufficient data handling and computation capacity. Despite these inadequacies, Taylor's Planning Office introduced many ideas and practices found in MRP. The importance of Taylor's system as a foundation for MRP can be shown. 
One key distinction between MRP and EOQ models was its recognition of time as an important factor. Evendell (1968) even describes it as the "most potent tool" available. His recognition was 50 years late:

There will be considerable differences in the time necessary for piloting the respective components through their various stages of production and this means that there ought to be all that difference in the time of starting work on the components, if delivery of the whole set or sets is to be synchronized at a given date. (Elbourne, 1918: 170) [Emphasis added]

so that: "The time at which the last component for a given complete product is finished virtually marks time of useful readiness of all the others." (Elbourne, 1918: 170) In Figure 2 Knoeppel (1920, Figure 109) presents an "ideal" schedule that coordinates production so that all items are available at the last moment needed, comparable to Orlicky's (1975) diagrams.

\section{Insert Figure 2 Here}

The most significant difference between OR-based EOQ models and MRP in practice arose from MRP's coordination of production lots without regard to their individual optimization. This idea dates to Taylor's system, as clearly implied by Knoeppel's Figure and Elbourne's comments above and more fully in Thompson's $(1914,1917)$ discussions. But it is absolutely clear and firmly dated to the mid-1940s as Figure 3, taken from (Moore, 1951) reveals. The 1940 s best practice in production planning systems used exactly the same logic as later MRP systems in making a level-by-level bill of material "explosion" complete with "netting". This is attributed to IBM and dates at least to 1945 where the graphic (though not the accompanying text) is in Alford and Bangs (1945: 231). This is comparable to an earlier, less succinct description in Thompson $(1914,1917)$. It processes data level by level, with higher level demands satisfied first by on-hand stocks at that level, and then projected requirements imposed down the product structure and accumulated until the items at that lower level are processed. 
This yields a detailed production plan for all finished items, assemblies, sub-assemblies, components and other inputs. This was considered a profound analysis of system operation when presented as an element of MRP. (Miller and Sprague, 1975)

\section{Insert Figure 3 Here}

The most useful feature of Orlicky (1975) are the tableaus that explicitly show the bill of material relationships, how current and planned inventories are used to determine net requirements, with lead-time offsetting yielding planned order releases; all over a fixed planning period. (Miller and Sprague, 1975) This too dates to the mid-1940s as seen in Koepke's (1949, 1954: 391; 1961: 151) presentation of the proto-tableau shown in Figure 4. It has gross requirements (row 1), netting against on-hand stocks with planned on-hand stocks (row 6), scheduled order receipts (row 3) and planned order releases (row 9). It aggregates independent and dependent demands to find an item's gross requirements. This shows links to lower level materials but does not show their tableaus. The inference that these materials were similarly managed is inescapable, but there is no documentation showing that. Other descriptions of the system's operations make that inference reasonable. DeCarlo (1955: 61) discusses a digital system in which end-item requirements drive the system: "From this will follow the computation of gross requirements, net requirements after processing with inventory files, and capacity requirements after scheduling." Wilson (2015) discusses a number of other 1950s articles describing the transition from accounting machine based production planning systems to digital versions. That culminates with Hill (1961) providing the best summary of an ideal punched-card based production control system. Wilson (2015) maintains that MRP's systems developers and users would have relied on their own experience with the earlier accounting machine 
implementations when designing and implementing digital systems. This tacit knowledge has not been well preserved or coherently expressed. (Orlicky, 1975: ix)

\section{Insert Figure 4 Here}

An earlier edition of Koepke (1941) lacks these tableaus so their creation appears to have arisen between 1941 and 1948 .

The Planning Office from Taylor's Shop Management provided a full-fledged production management system. (Taylor, 1903, 1911; Thompson, 1914, 1917) Figure 5 shows a flow chart illustrating a 1940s production planning and control system (Moore, 1951: 332). This was implemented on accounting machines (Alford and Bangs, 1945) that were crude, slow and limited compared to modern digital computers. Alford and Bangs (1945: 230) describe an accounting machine based system used to control the production of over 1,600 end items made from 58,000 components using 8,000 different raw materials and another 14,000 purchased components. Of these, $60 \%$ of the components were used in multiple products, and there were significant differences in their lead times for both make-to-stock and make-to-order items. To further complicate matters there were large variations in sales. This was a real, working system rather than one theorized as possible; never-the-less, it seems that like early MRP systems there were undoubtedly few that were completely implemented or fully effective in use.

\section{Insert Figure 5 Here}

An evolving and increasingly complex presentation of the Planning Office's functions may be observed in the increasing sophistication of flow-charts from Sterling (1914) to Diemer (1914) and then with Kimball (1925) and Knoeppel (1920), culminating with Schlesinger (1949, Figure 47) and Moore (1951). The underlying logic and structure throughout them all is taken from Taylor's Planning Office. 


\section{Lean: Then vs Now}

The OM literature ignores other historic alternatives to EOQs. As noted above, operations managers found EOQs inappropriate within production systems, and this dis-satisfaction became more general in the 1980s and later. Although the policy of buying just what was needed for when it was needed was not formally part of Taylor's system, at that time it appears to have been normal practice generally and thus very likely to have been used by default within Taylor's system. Whitin (1953) mentions "hand-to-mouth buying," a lean approach in which producers make or buy only enough for immediate needs. This policy became dominant after a crisis in 1921 when a sales contraction left many companies with excessive inventories. (Clark, 1927-8; Tosdal, 1932-3) The survey undertaken by Lyon (1929) shows it to have been widely used with "general and profuse" discussions. "Hand-to-mouth" buying remained popular despite the EOQ's development, though Lyon notes "The increasing acceptance of engineering ideals in production has, particularly during the past 15 years, been working its way into the buying and selling function." implicitly referring to Harris (1915). He speculates that increasing numbers of Business Schools will promote those methods. Indeed, Taylor's work created an atmosphere that encouraged such theorizing. Lean manufacturing may be rediscovering historic policies linking production to customer needs. The strategic pressures Lyon found favoring "hand-to-mouth" buying in the 1920 s remain even today.

Ford (1924: 143) commented that they bought materials for "immediate needs" only and if transport were perfect “...it would not be necessary to carry any stock whatsoever.” Elbourne (1918: 153) suggested that: "... the practice of ordering practically all material only as and when required to meet specific orders has a great deal to recommend it." to avoid excessive 
inventories. Despite that, production for stock could be useful so he suggested a reorder point technique, with implicit safety stocks:

Not only should the ordering level be fixed but also the normal quantity to be ordered, and both must have regard to the time required for obtaining fresh supplies and the liability of the stock becoming exhausted meantime. (1918:154)

The lot sizing technique is not described and no consistent method seems used. Lead-time offsetting is seen again, and there are implied safety stock concerns too. It appears that normal purchasing and operations followed lean principles, and that when lot sizing was done it informally followed many of the ideas used later within EOQ formulations. These are all seemingly de facto "lean" operations, with minimal work-in-process inventories.

\section{Production Planning: Then vs Now}

There is an intimate connection between Gantt's Charts and Taylor's Shop Management since they were sequentially published as papers 1002 (Gantt, 1903) and 1003 (Taylor, 1903) in the same issue of the ASME Transactions and meant to be read together as mutually supporting. (Copley, 1923) Gantt Charts were intended to be a general production planning tool for capacity planning and work flow management that were critical for managing a factory's operations. Clark (1922) describes how Gantt charts were used for meeting customer requirements:

If a promise of a delivery is to be kept, all the work in a plant must be planned so accurately that when a new order is received, it is possible to tell almost to a day when the work will be completed. The Gantt Progress Chart enables the manager to keep before him all the promises he has made, to concentrate his attention on overcoming obstacles and avoiding delays, and, when it is impossible to live up to a promise, it enables him to give the customer advance notice of the fact. (Clark, 1922: 84)

In this quotation there are three notable points:

1. The whole of the production process was to be considered since Clark requires "all the work" to be planned and controlled. Taylor subordinated the activities of individual workers and work centers to the demands of the system as a whole. 
2. The "all the promises" implies that the factory is driven by sales, without prioritization and with no juggling of commitments satisfying current needs (e.g. "rush" orders) using resources meant for future use (regular orders for normal delivery).

3. If the schedule is to be accurate "almost to a day" then planning had to be precise. Delays and inefficiency could not be tolerated, and uncertainty would have been eliminated. Contemporary piece rate payment systems were a self-enforcing quality assurance and motivation system.

Although sales drove production plans these were also constraints on later sales. Existing sales dictated existing production plans with delivery dates being firm commitments to existing customers. New orders were scheduled as received, by their required delivery dates and had to fit in around existing production and sales obligations. (Clark, 1922, Appendix 1) Once a commitment to sales was made the management then had a firm obligation to meet.

The importance of production planning is highlighted by the significance placed on Holt, Modigliani, Muth and Simon's (1960) linear decision rule model for aggregate planning. (Singhal and Singhal, 2007) Gantt's Charts were still widely used in the 1950s but the increasing complexity and volume of work made their use managing factories impractical. Scientific Management attempted to deal with production planning, but its approach could not keep pace with increasing workloads, and while the HMMS approach was suitable for aggregate planning resolving the needs for detailed production planning required significantly greater computing power unavailable until much later. Detailed production planning is a very difficult problem that no technique in the 1960s could solve, Scientific Management found it overwhelmed that capabilities of Gantt charts, and the Management Science oriented Linear Decision Rule could only deliver a broad, strategic level resolution rather than a low level production plan. It defeated both. 


\section{Flexible Fordism vs Assembly Line Balancing}

Assembly line balancing (ALB) provides a clear before-and-after case, with Salveson (1955) identifying a problem suitable for optimization: minimizing wasted time subject to throughput demands and technical constraints in workload assignment and sequencing. The objective, of balancing work across the line's workstations was recognized and implemented with the very first lines created by Ford in 1913. Wilson and McKinlay (2010) describe line balancing as a practical matter: Ford's managers already had four years' experience making Model Ts and could initially allocate work evenly using that knowledge; and then when the trial line was running, they could easily see which workers had too much to do, and those that had too little, and the line reconfigured to achieve a balance without great difficulty, or any computation.

Wilson $(2010,2014)$ argues that our understanding of assembly lines is implicitly constrained by the theory surrounding ALB describing how such systems should be designed for maximum efficiency. Line balancing since Salveson (1955) has focused on maximizing line efficiency rather than overall operational effectiveness or strategic use. Erel and Sarin (1998) see that ALB theory is not widely used. They suggest practitioners are unfamiliar with the relevant theoretical developments but also recognize managers must consider broader issues than optimization. The existing literature in both OM and OR ignores assembly line practice before Salveson's (1955) work; despite universal acknowledgement that Ford used them first. An analysis of Ford's assembly line (Wilson, 1996; Wilson and McKinlay, 2010; and Wilson, 2014) reveals how lines may be used more flexibly, within a supply-chain perspective dynamically linking both suppliers and customers. Ford informally used the objectives and logic that Salveson (1955) later formalized. Wilson and McKinlay (2010) and Wilson (2014) recognize Ford used multiple parallel lines to vary output responding to substantial fluctuations in sales: Ford used 
four lines when demand was high, three when it was average and just two when it was lowest. Figure 6 illustrates how closely Ford matched production to highly variable sales just before and during their introduction of the assembly line. Ford considered the lines "locally" as individual production systems; and "globally" within their highly integrated supply chain system (Ford, 1924; Wilson, 1995a, 1996). The need for flexible as well as high-volume production seems to have been better understood by Ford than by those that followed him.

\section{Insert Figure 6 Here}

\section{Operations Research and Existential Threats}

Operations research itself has experienced an existential threat since the late 1970s. Ackoff (1979) has been the most prominent and persistent critic (Kirby, 2000) but the feeling that the discipline is threatened is widespread, Dando and Bennett (1981), van Gigch (1989), Sodhi and Tang (2008) all describe their concerns. Corbett and van Wassenhove (1993) speak of a "natural drift" that has affected the discipline, observing that the demands for academic rigor are natural for a University based discipline, but lead to research that is increasingly irrelevant to business people and practitioners: it becomes self-referential when academics descend to speaking only to other academics. Corbett and van Wassenhove (1993, Figure 1) plot the decline in OR oriented articles since 1971 in the Harvard Business Review in contrast to their growth in the previous 15 years. This reflects Abbott's (1988) concept of "regression" in which professions move away from their origins in practical applications towards greater theorization and abstraction.

Denizel, Usdiken and Tuncalp (2003) question this view from a global perspective, noting that the OR in the UK has followed a more practitioner-oriented path (Kirby and Capey, 1998) despite the "scientific-orientation" remaining dominant in the US; but with trends in the 
rest of the world moving towards more practitioner-oriented research after having followed the US lead. This is reinforced by Kirby (2000, 2001, 2003a) and Rosenhead (2009) showing the UK has a divergent history, with applications remaining a more important feature of UK based OR practice and research. Checkland's $(1981,2001)$ Soft Systems Methodology is perhaps the most significant alternative to US dominated approaches, although it remains less utilized than the "classic" methods. (Kirby, 2007)

Within the US, however, Albritton, McMullen and Gardiner (2003: 88) note a marginalization of OR within the Business School curriculum, and observe that it is often taken within other disciplines. One remarkable point is that these critiques ignore $\mathrm{OM}$ almost completely, it is occasionally mentioned as another discipline but the mutual interests and foci of the two are simply not considered. For two disciplines that are so closely linked this myopia is odd, particularly since recent Business School rationalization efforts have in many cases amalgamated OR with OM or information management. (Albritton, McMullen and Gardiner, 2003) Indeed, Corbett and van Wassenhove (1993: 627) suggested an intermediary between theorists and practitioners they call "management engineers" and describe a role that sounds much like that assumed by OM specialists when deploying OR tools.

Sodhi and Tang (2008: 270) take an "ecosystem" perspective without expressly considering $\mathrm{OM}$ as a close competitor (or even a "predator"!), though they do recognize “... domains of applications have long co-opted these tools and techniques...." ironically ignoring that OR "co-opted" many OM applications in its youth. They bemoan the fact that OR has become viewed as a "tool oriented discipline." There was, and remains an active debate on the role of OR (Keys, 1989; Miser, 1991; Keys, 1998) Hansen (1989) considers several possible reasons for the declining status of OR and suggests that "counter-performance" might be 
considered the most significant — applications where the models are ineffective. Mitroff and Silvers (2010) note the criticism that someone with a hammer considers every problem a nail has been justifiably levelled against some operations researchers. Fitting the problem to the capabilities of the tools can yield powerful analyses in some clearly defined cases, but it may yield impractical and even counter-productive recommendations in others. In particular, it can provide powerful solutions to narrowly defined problems while ignoring larger, more important issues affecting process and organizational effectiveness. And it is in considering those larger perspectives that OM seems more effective. From an OM perspective Fuller and Mansour (2003) and Fuller and Denton (2006) explicitly consider the large overlap in many topics they cover, and suggest that $\mathrm{OM}$ is broader and more managerial while OR simply provides the tools to be used-a subservient kind of position. The threat OR once posed for OM seems to have reversed.

The broadening perspective taken by $\mathrm{OM}$ can be seen in other areas as well. Although work-study and job design were significant elements of Taylor's work, and scientific management (Taylor, 1904, 1913; Gilbreth, 1912; Gilbreth and Gilbreth, 1918) they were largely shed in the 1960s reinvention and seldom appear in current OM texts. These topics are now dealt with by industrial engineers as they concern individual workers and their tasks. Operations management continues to focus on work and work flows, but that attention has evolved away from looking only at individuals to a wider focus on work within groups, then between groups within organizations; and culminating with considerations of how organizations interact. This widening perspective can be traced through the literature, moving beyond Taylor and the Gilbreths, to consider groups with the genre of "Organization and Methods" studies (Dovey, 1953; Unattributed, 1970; Addison, 1971; Webster, 1973) that was then displaced by the similarly focused Business Process Reengineering movement (Hammer, 1990; Davenport and 
Short, 1990; Hammer and Champy, 1993). The movement within OM to increasingly integrate operations then extended to considering whole supply chains and networks. The current dominant focus for the discipline is supply chain management, with an extension literature following from Cooper, Lambert and Pagh (1997). Ironically, this replicates in a less formal manner Ford's vertically integrated manufacturing operations that sought to control all stages of the production process, with Ford owning mines, plantations and tracts of forest as sources for their materials, shipping and rail companies to transport them; with schools and welfare officers to monitor and help make better employees of his staff, internal factory controls for not just the production processes but including a factory police force active in suppressing unions and discontented workers, and culminating in an extensive dealer network under strict contractual obligations to the company. (Ford, 1924, 1926; Chandler, 1964; Wilson, 1996; Nevins and Hill, 1954, 1957) Ford understood supply chain management but such extensive and tight control could not be maintained. Nevertheless, both Ford and Taylor are recognized as being systems builders-Ford through his business structure and Taylor through his efforts to systemize management. (Litterer, 1961, 1963; Kanigel, 1997) With the advent of computing in the 1950s the interest in systems became more formalized. (Checkland, 1983) This perspective is emphasized by OM embracing "systems thinking” and holistic approaches. (Starr, 1996)

\section{Reinvention and Reuse-Scientific Management's Unseen Revival}

Operations Management has undergone a revival since the 1960s with Buffa's synthesis defining it as a "modern" discipline. Scientific Management played an unseen and unappreciated but significant role in that revival. Many of the current interests of the discipline are known to originate with Scientific Management itself and other contemporary management development. 
At a critical time for $\mathrm{OM}$ as a distinct discipline Scientific Management concepts and practices directly contributed to MRP design and operation: concepts like time-phasing, lot size coordination, level-by-level requirements calculations can all be traced to the Planning Office. Taylorism is often seen as an ideology (Braverman, 1974) or somewhat disreputable from sociological or psychological perspectives (Boddewyn, 1961; Nyland, 1987; Kanigel, 1997; Guillén, 1997; and Wagner-Tsukamoto, 2008) but despite those criticisms its effects are widely understood to be pervasive (Kanigel, 2002) in management. But Scientific Management is more than an ideology or philosophy: it has provided many of the essential tools used by Operations Managers for managing "modern" production.

\section{Conclusions \& Portents for the Future}

The challenge of the early 1960s with its demands for "scientific" rigor and the existential threat from the new discipline of Operations Research was successfully met. There was an OM revolution in 1960s and 1970s: Buffa (1961) redefined the discipline, Skinner (1969) refocused it and Orlicky (1975) with the practitioner lead MRP revolution revitalized and grounded it in a practical reality. Perhaps the most significant insight from a post-modern deconstruction of Operations Management's re-invention has been the importance of its engagement with practitioners. Historically with Taylor's Planning Office that was well grounded in the practical needs of shop management, in the recent past with Materials Requirements Planning and lean approaches, with its current engagements via APICS; and keen interest in future industrial and service developments.

But evolution doesn't stop, and disciplines must constantly adapt to a changing intellectual ecology. Operations Management has come to focus on services as those have become increasingly important in national economies and its traditional engagements with 
inventory management and physical production became less relevant. It has also increased its interests in international operations with a re-emphasis on logistics. Notably, Supply Chain Management has become more prominent with the practitioner body $A P I C S$, merging with American Society of Transportation and Logistics in 2015, (APICS, 2015) and with the Supply Chain Council in 2014 (APICS, 2017). Academicians are following, with the Academy of Management's Operations Management Division renamed as the Operations \& Supply Chain Management Division. This identification with supply chain management parallels industry; but, the further differentiation of management expertise may be seen in the rise since the mid-1990s of organizations such as the Project Management Institute (PMI) and the British Association of Project Managers (APM) that focus exclusively on projects. There are Journals such as the International Journal of Project Management and the Project Management Journal supporting this differentiation. APICS seems to be mimicking PMI (Unattributed, 2013) with its own "Book of Knowledge" (APICS, 2017) Project management thus seems destined to remain as a separate discipline and become established as a distinct profession (already having its own professional examinations with certifications). Nevertheless, it and OM will continue to share interests, just as $\mathrm{OM}$ and OR have done in the past. Fragmentation into more specialist disciplines will remain a threat as production modes evolve, and the core concerns of Operations Management may similarly reflect environmental change without necessarily abandoning its past, as they always have.

\title{
Bibliography
}

\author{
Abbott, A., 1988. The System of Professions, The University of Chicago Press, Chicago, Ill. \\ Academy of Management, 2017. OSCM Newsletter, oscm.aom.org/wp- \\ content/uploads/2016/11/Fall-2016-Vol.-43-Issue-2.pdf, accessed 10 October, 2017.
}


Ackoff, Russell L., 1979. "The future of Operational Research is Past," The Journal of the Operational Research Society, Vol. 30, No. 2, p. 93 - 104.

Addison, Michael, 1971, Essentials of Organization and Methods, William Heinemann, Ltd., London, England.

Albritton, M. David, Patrick R. McMullen and Lorraine R. Gardiner, 2003. "OR/MS Content and Visibility in AACSB-Accredited US Business Programs," Interfaces, Vol. 33, No. 5, p. 8389.

Alford, L. P. \& J. R. Bangs. 1945. Production handbook, Ronald Press Co., New York, New York.

Andrew, Charles G. and George A. Johnson, 1982. "The Crucial Importance of Production and Operations Management," The Academy of Management Review, Vol. 7, No. 1, p. 143-147.

Anonymous, 1997. "Said Business School: Verbatim Report of Proceedings in Congregation," Oxford University Gazette, Supplement (2) to Gazette No. 4442, $23^{\text {rd }}$ June 1997:

www.ox.ac.uk/gazette/1996-7/supps/2_4442.htm accessed $6^{\text {th }}$ January, 2014.

Anonymous, 2012. "Hypermodernity," en.wikipedia.org/wiki/Hypermodernity, accessed $6^{\text {th }}$ January, 2013.

APICS, 2015. News Release, www.apics.org/about/overview/apics-newsdetail/2015/07/15/apics-finalizes-merger-with-american-society-of-transportation-andlogistics, accessed 10 October, 2017.

APICS, 2017. About APICS page, www.apics.org/about/overview/about-apics-scc, accessed 10 October, 2017.

APICS, 2017. Individual Member Services page, www.apics.org/apics-for-individuals/apicsmagazine-home/resources/ombok, accessed 10 October, 2017.

Babbage, Charles. 1832. On the Economy of Machinery and Manufactures, Charles Knight, London, England.

Bayraktar, Erkan, M.C. Jothishankar, Ekrem Tatoglu and Teresa Wu, 2007. "Evolution of operations management: past, present and future," Management Research News, Vol. 30 No. 11, p. $843-871$.

Bloom, Allan, (Trans.) 1968. The Republic of Plato. Translated, with notes and an interpretive essay. Basic Books, New York, N.Y.

Boddewyn, J. 1961. "Frederick Winslow Taylor Revisited," The Journal of the Academy of Management, Vol. 4, No. 2, p. 100-107.

Braverman, Harry, 1974. Labor and Monopoly Capital: The Degradation of Work in the Twentieth Century, Monthly Review Press, New York, New York.

Buffa, Elwood S., 1961. Modern Production Management, Wiley, New York, New York.

Buffa, Elwood S., 1965. Modern Production Management, Second Edition, Wiley, New York, New York.

Buffa, Elwood S., 1969. Modern Production Management, Third Edition, Wiley, New York, New York. 
Buffa, Elwood S., 1980. "Research in Operations Management," Journal of Operations Management, Vol. 1, No. 1, p. 1 - 7.

Cadbury, E. 1914, "Some Principles of Industrial Organization, the case for and against Scientific Management," Sociological Review, Vol. 7, No. 2, p. 99-117.

Chandler, A. D. 1964. Giant Enterprise: Ford, General Motors, and the Automobile Industry, Harcourt, Brace and World, Inc., New York, New York.

Chase, Richard B. and Eric L. Prentis, 1987. "Operations Management: A Field Rediscovered," Journal of Management, Vol. 13, No. 2, p. 351 - 366.

Checkland, Peter B., 1981, Systems Thinking, Systems Practice, John Wiley \& Sons, Ltd. London, England.

Checkland, Peter B., 1983, “OR and the systems movement: mappings and conflicts," Journal of the Operational Research Society, Vol. 34, No. 8, p. 661-675

Checkland, Peter B., 2001, "Soft Systems Methodology," in J. Rosenhead and J. Mingers (eds), Rational Analysis for a Problematic World Revisited. Wiley, Chichester, England.

Chopra, Sunil, William Lovejoy and Candace Yano, 2004. "Five Decades of Operations Management and the Prospects Ahead," Management Science, Vol.50, No. 1, p. 8-14.

Clark, W. 1922. The Gantt chart, The Ronald Press Co., New York.

Clark, F. E. 1927-8. "An analysis of the causes and results of hand-to-mouth buying," Harvard Business Review, Vol. 6, p. 394-400.

Cooper, Carolyn C. 1981-2. "The Production Line at Portsmouth Block Mill,” Industrial Archaeology Review, Vol. 6, No. 1, p. 28-44.

Cooper, Carolyn C. 1984. "The Portsmouth System of Manufactures," Technology and Culture, Vol. 25, No. 2, p. 182-225.

Cooper, M.C., Lambert, D.M., \& Pagh, J., 1997, "Supply Chain Management: More Than a New Name for Logistics," The International Journal of Logistics Management, Vol. 8, No. 1, p 114.

Copley, Frank Barkley, 1923. Frederick W. Taylor: Father of Scientific Management, Reprinted 1969, Augustus Kelley, New York.

Corbett, Charles J. and Luk N. van Wassenhove, 1993. "The Natural Drift: What Happened to Operations Research?” Operations Research, Vol. 41, No.4, p. 625-640.

Cortada, James W., 2003. The Digital Hand: How Computers Changed the Work of American Manufacturing, Transportation, and Retail Industries, Oxford University Press, Oxford, England.

Craighead, Christopher W. and Jack Meredith 2008. "Operations management research: evolution and alternative future paths," International Journal of Operations \& Production Management, Vol. 28 No. 8, p. 710-726.

Cummings, Stephen, 2002. ReCreating Strategy, Sage, London.

Dando, M. R. and P. G. Bennett, 1981. “A Kuhnian Crisis in Management Science?” The Journal of the Operational Research Society, Vol. 32, No. 2, p. 91-103. 
Davenport, Thomas \& Short, J., 1990, "The New Industrial Engineering: Information Technology and Business Process Redesign", in: Sloan Management Review, Vol. 31, No. 4, p 11-27.

Davis, R.C. 2007. Shipbuilders of the Venetian Arsenal: Workers and Workplace in the PreIndustrial City. The Johns Hopkins University Press, Baltimore, Md.

DeCarlo, C.R., 1955. "Applications of Data Processors in Production," AFIPS Proceedings of the Western Joint Computer Conference, p 61-65.

Defoe, Daniel. 1697. An Essay Upon Projects. Reprinted 1887. Cassell \& Co., London, England.

Denizel, Meltem, Behlul Usdiken and Deniz Tuncalp, 2003. "Drift or Shift? Continuity, Change, and International Variation in Knowledge Production in OR/MS," Operations Research, Vol. 51, No. 5, p. 711-720.

Diemer, Hugo, 1914. Factory Organization and Administration, McGraw-Hill Book Co., Inc., New York, New York.

Dovey, H. O. 1953. Handbook of Organisation and Methods Techniques, The International Institute of Administrative Sciences, Brussels, Belgium.

Drucker, Peter F., 1955. The Practice of Management, William Heinemann, Ltd., London, England.

Edwards, Roy, 2010. "Job analysis on the LMS: mechanisation and modernisation c.1930c.1939,” Accounting, Business and Financial History, Vol. 20, No. 1, p. 91-105.

Edwards, Roy, 2011. "Divisional Train Control and the Emergence of Dynamic Capabilities: The Experience of the London, Midland and Scottish Railway, c1923-c1939." Management and Organizational History. Vol. 6, No. 4, p. 391-410.

Elbourne, Edward D., 1918. Factory Administration and Accounts, Third Edition. The Library Press Co., Ltd., London, England.

Emerson, Howard P. and Douglas C. E. Naehring, 1988. Origins of industrial engineering: the early years of a profession, Industrial Engineering \& Management Press, Peachtree Corners, Georgia, USA.

Emiliani, M.L. and P.J. Seymour, 2011. "Frank George Woollard: forgotten pioneer of flow production," Journal of Management History, Vol. 17 No. 1, p. 66-87.

Erel, E., and S.C. Sarin, 1998. "A Survey of the assembly line balancing procedures," Production Planning \& Control, Vol. 9, No. 5, p. 414-434.

Erlenkotter, Donald, 1990. "Ford Whitman Harris and the Economic Order Quantity Model," Operations Research, Vol. 38, No. 6, p. 937-946.

Evans, Oliver. 1795 (Reprinted 1989). The Young Mill-wright \& Miller's Guide. Arno Press. New York, New York.

Evendell, R., 1968. “Time phasing: The most potent tool yet for slashing inventories," Modern materials handling, November, p. 53-59.

Fayol, Henri, 1930. Industrial and General Administration. Translated by J.A. Coubrough, Sir Isaac Pitman \& Sons, London, England. 
Ford, Henry (collaboration with Crowther, S.), 1924. My Life \& Work, William Heinemann Ltd., London, England.

Ford, Henry (in collaboration with Samuel Crowther).1926. Today and Tomorrow, William Heinemann Ltd., London.

Foucault, Michel, 1969 (2002 Tr.). The Archaeology of Knowledge, A. M. Sheridan Smith (Tr.). Routledge, London, England.

Fry, Timothy D. and Joan M. Donohue, 2013. "Outlets for operations management research: a DEA assessment of journal quality and rankings," International Journal of Production Research, Vol. 51, No. 23-24, p. 7501-7526.

Fuller, Jack A. and Ali H. Mansour, 2003. "Operations management and operations research: a historical and relational perspective," Management Decision, Vol. 41 No. 4, p.422 - 426.

Fuller, Jack A. and James W. Denton, 2006. "Future Directions Of Management Science And Operations Management In Business School Curricula," College Teaching Methods \& Styles Journal. Vol. 2, No. 3, p. 29-32.

Gantt, H. L., 1903. "A graphical daily balance in manufacture,” ASME Transactions, Vol. 24, p. 1322-1336.

Garside, W.R. and J.I. Greaves, 1997, "Rationalisation and Britain's Industrial Malaise: the Interwar Years," Journal of European Economic History, Vol. 26, No. 1, p. 37-68.

Garvin, W. W., Crandall, H. W. John, J. B. and Spellman, R. A. 1957, “Applications of Linear Programming in the Oil Industry,“ Management Science, Vol. 3, No 4, p. 407-430.

Gieryn, Thomas F. 1983. "Boundary-Work and the Demarcation of Science from Non-Science: Strains and Interests in Professional Ideologies of Scientists," American Sociological Review, Vol. 48, No. 6. p. 781-795.

Gilbreth, Frank B. 1912. Primer of Scientific Management, D. Van Nostrand Co., New York, New York.

Gilbreth, Frank B., Lillian M. Gilbreth. 1918. Applied Motion Study, George Routledge \& Sons, Ltd., London, England.

Gilbert, James P. and Richard J. Schonberger. 1983. Inventory Based Production Control Systems: A Historical Analysis. Production and Inventory Management, Vol. 24, No. 2, p. 114.

van Gigch, John P., 1989. "The Potential Demise of OR/MS: Consequences of neglecting epistemology," European Journal of Operational Research, Vol. 42, No. 3, p. 268-278.

Gimpel, Jean, 2007. The Medieval Machine: The Industrial Revolution of the Middle Ages, Penguin, London, England.

Goodrick, Elizabeth, 2002. "From Management as a Vocation to Management as a Scientific Activity: An Institutional Account of a Paradigm Shift," Journal of Management, Vol. 28, No. 5, p. 649-669

Gordon, Robert A. and James E. Howell, 1959. Higher Education for Business, Columbia University Press, New York, New York. 
Gould, Stephen Jay, and Niles Eldredge, 1977. "Punctuated equilibria: the tempo and mode of evolution reconsidered," Paleobiology, Vol. 3, No. 2, p. 115-151.

Guillén, Mauro F., 1997. "Scientific Management's Lost Aesthetic: Architecture, Organization and the Taylorized Beauty of the Mechanical." Administrative Science Quarterly, Vol. 42, No. 4, p. 682-715.

Hall, Nicholas G. and Michael Magazine, 2003. "Scheduling and Sequencing," in The Encyclopedia of Operations Research and Management Science, Saul I. Gass and Carl M. Harris (Eds.), Kluwer Academic Publishers, Boston, Ma., p. 1356-1363.

Hammer, M., 1990, "Reengineering Work: Don't Automate, Obliterate", Harvard Business Review, Vol. 76, No. 4, p. 104-112.

Hammer, M. and Champy, J. A., 1993, Reengineering the Corporation: A Manifesto for Business Revolution, Harper Business Books, New York, N.Y.

Hansen, Pierre, 1989. "A short discussion of the OR crisis," European Journal of Operational Research, Vol. 38, No. 3, p 277-281.

Harris, F.W. 1915. Operations and Cost, Factory Management Series, A.W. Shaw Co., Chicago, Ill.

Hill, L. S. 1961. A model punched card system for production control. Rand Corp., Santa Monica, Cal.

Hills, Richard L., 1993. Power from Wind: A History of Windmill Power, Cambridge University Press, Cambridge, England.

Hounshell, David A., 1988. "The Same Old Principles in the New Manufacturing," Harvard Business Review, Vol. 66, No. 6, p. 54-61.

Hounshell, David, 1984. From the American System to Mass Production 1800-1932, John Hopkins University Press, Baltimore, Md.

Holt, C. C., F. Modigliani, J. F. Muth and H. A. Simon, 1960. Planning Production, Inventory and Workforce, Prentice-Hall, Englewood Cliffs, New Jersey.

International Journal of Operations and Production Management, 2017, "Mission and Scope," International Journal of Operations and Production Management website:

http://emeraldgrouppublishing.com/products/journals/journals.htm?id=ijopm, accessed $9^{\text {th }}$ October, 2017.

International Journal of Production Research, 2017, “Aims and Scope”, International Journal of Production Research website:

www.tandfonline.com/action/journalInformation?show=aimsScope\&journalCode=tprs20, accessed $9^{\text {th }}$ October, 2017.

Jenkins, Terry, 2011. Sir Ernest Lemon: the production engineer who modernised the LMS railway and equipped the RAF for war: a biography. Railway \& Canal Historical Society, Oxford, England.

Johnson, S. M., 1954. "Optimal Two- and Three-Stage Production Schedules With Set-up Time Included," Naval Research Logistics Quarterly, Vol. 1, No. 61-68. 
Journal of Operations Management, 2017, “Journal Aims \& Scope”, Journal of Operations Management, webite: www.journals.elsevier.com/journal-of-operations-management, accessed 9 October, 2017.

Juran, Joseph M., (Ed.) 1995, A History of Managing for Quality: The Evolution, Trends, and Future Directions of Managing for Quality, The American Society for Quality Control, Milwaukee, Wisconsin.

Kanigel, R., 1997. The One Best Way: Frederick Winslow Taylor and the Enigma of Efficiency, Abacus, London, England.

Keys, P., 1989. “OR as technology: Some issues and implication,” Journal of the Operational Research Society, Vol. 40, p. 753-759.

Keys, P., 1998. “OR as technology revisited," Journal of the Operational Research Society, Vol. 49, p. 99-108.

Kharbe, A. S., 2009. English Language and Literary Criticism, Discovery Publishing House: New Delhi, India.

Kimball, Dexter S., 1925. Principles of Industrial Organization, Third Edition. McGraw-Hill Book Co., New York, New York.

Kirby, Maurice W., 2000. “Operations Research Trajectories: The Anglo-American Experience from the 1940s to the 1990s," Operations Research, Vol. 48, No. 5, p. 661-670.

Kirby, Maurice W. 2001, "History of early British OR," in Encyclopedia of Operations Research and Management Science, Saul I. Gass and Carl M. Harris (eds.), Springer US, New York, N.Y., USA, p 366-369.

Kirby, M. W., 2003a. Operational Research in War and Peace: The British Experience from the 1930s to 1970, Imperial College Press, London, England.

Kirby, Maurice W., 2003b. "The Intellectual Journey of Russell Ackoff: From OR Apostle to OR Apostate," The Journal of the Operational Research Society, Vol. 54, No. 11, p. 1127-1140

Kirby, Maurice W., 2007, "Paradigm change in Operations Research: thirty years of debate," Operations Research, Vol. 55, No. 1, p1-13.

Kirby, M.W. and Capey, R. (1998). "The Origins and Diffusion of Operational Research in the UK." The Journal of the Operational Research Society. Vol. 49, No. 4, p. 307-326.

Kleinrock, Leonard, 1975, Queueing Systems, Volume I, John Wiley \& Sons, New York, N.Y.

Knoeppel, C., 1920. Graphic production control, New York: The Engineering Magazine Company.

Koepke, Charles A., 1941. Plant Production Control, First Edition, John Wiley \& Sons, New York, N.Y.

Koepke, C. A., 1949. Plant production control, Second Edition. John Wiley \& Sons, New York, N.Y., USA

Koepke, C. A., 1954. Plant production control, Second Edition. Fifth Printing. John Wiley \& Sons, New York, N.Y. 
Koepke, C. A., 1961. Plant production control, Third Edition. John Wiley \& Sons, New York, N.Y.

Kozak-Holland, Mark, 2011. The History of Project Management, Multi-Media Publications Inc., Newtown Square, Pa., USA

Lazonick, William. 1981. "Production Relations, Labor Productivity and Choice of Technique: British and U. S. Cotton Spinning," Journal of Economic History, Vol. 41, No. 3, p. 491-516.

Lewchuck, Wayne A., 1984, "The role of the British Government in the Spread of Scientific Management and Fordism in the interwar years," The Journal of Economic History, Vol. 44, No. 2, p. 355-361.

Lewchuck, W.A., 1985, “The Origins of Fordism and Alternative Strategies: Britain and the United States, 1880-1930." In S. Tolliday and J. Zeitlin (eds.) Between Fordism and Flexibility, Oxford University Press, Oxford, England.

Litterer, J. 1961, "Systematic Management: The Search for Order and Integration,” Business History Review, Vol. XXXV, No. 2, p. 461-76.

Litterer, J. 1963, "Systematic Management: Design for Organisational Recoupling in American Manufacturing Firms," Business History Review, Vol. XXXVII, No. 4, p. 369-91.

Lucas, Adam, 2006. Wind, Water, Work: Ancient and Medieval Milling Technology, Brill Publishers, Leiden, Netherlands.

Lummus, R.R., 2007. "The role of APICS in professionalizing operations management," Journal of Operations Management, Vol. 25, No. 2, p. 336-345.

Lyon, L. S., 1929. Hand-to-mouth buying, The Brookings Institution, Washington, D.C.

Lyotard, Jean-François. 1979. The Postmodern Condition: A Report on Knowledge, Geoff Benington and Brian Massumi (Trans.), Manchester University Press, Manchester, England.

Mabert, Vincent A. 2007. The Early Road to Materials Requirements Planning. Journal of Operations Management. Vol. 25, No. 2, p. 346-356.

Major, J.Kenneth, 2008. Animal-powered Machines, Bloomsbury Publishing, Londeon, England.

Mayr, Otto, 1970, The Origins of Feedback Control, MIT University Press, Cambridge, Ma.

McFarland, Dalton E., 1960. "The Emerging Revolution in Management Education." The Journal of the Academy of Management, Vol. 3 No. 1, p. 7-15.

Mckay, K. N., 2003. "Historical survey of manufacturing control practices from a production research perspective," International Journal of Production Research, Vol. 41, No. 3, p. 411426.

Meredith, Jack R. Amitabh Raturi, Kwasi Amoako-Gyampah and Bonnie Kaplan' 1989. "Alternative research paradigms in operations," Journal of Operations Management, Vol. 8, No. 4, P. 297-326.

Meredith, Jack R. and Kwasi Amoako-Gyampah, 1990. "The Genealogy of Operations Management," Journal of Operations Management, Vol. 9, No. 2, P. 146-166.

Merrick, Charles M. (ed.) 1984. ASME Management Division History, 1886-1980. ASME, New York, New York. 
Miller, Jeffrey G. and Linda G. Sprague, 1975. "Behind the Growth in Materials Requirements Planning," Harvard Business Review, Vol. 53, No. 5, p. 83-91.

Miser, H., 1991. "Comment on 'OR as technology'," Journal of the Operational Research Society, Vol. 42, p. 429-431.

Mitroff, I.I., and Silvers, A., 2010. Dirty Rotten Strategies: How We Trick Ourselves and Others into Solving the Wrong Problems Precisely, Stanford, Ca.: Stanford University Press.

Mitzman, Arthur, 1970. The Iron Cage: An Historical Interpretation of Max Weber. Transaction Books, New Brunswick N.J.

Moore, F. G. 1951. Manufacturing management. Richard D. Irwin, Inc., Homewood, Ill.

Mulligan, Thomas H., 1987. "The Two Cultures in Business Education," The Academy of Management Review. Vol. 12, No. 4, p. 593-599.

Naylor, Thomas H. The 1950-1970 Business School Coup d'Etat and the 2008 Wall Street Meltdown. From vermontrepublic.org/the-1950-1970-business-school-coup-detat-and-the2008-wall-street-meltdown/ accessed 6/1/2014.

Neely, Andy, 1993. "Production/Operations Management: Research Process and Content during the 1980s," International Journal of Operations \& Production Management, Vol. 13, No. 1, p.5-18.

Nevins, Allan, and Frank Hill. 1954, Ford: The Times, The Man, The Company, Scribner, New York.

Nevins, Allan, and Frank Hill. 1957, Ford: Expansion and Challenge: 1915-1933, Scribner, New York.

Nyland, Chris, 1987. "Scientific management and planning," Capital \& Class, Vol. 11, p. 55-83.

Orlicky, J., 1975. Materials requirements planning, McGraw-Hill Book Co., New York.

Pannirselvam, Gertrude P; Ferguson, Lisa A; Ash, Robert C; Siferd, Sue P., 1999. "Operations management research: an update for the 1990s," Journal of Operations Management, Vol. 18 , No. 1, p. $95-112$.

Piercy, Niall, 2012. "Business history and operations management." Business History, Vol. 54, Vol. 2, p. 154-178.

Pierson, Frank Cook, 1959. The Education of American Businessmen: A Study of UniversityCollege Programs in Business Administration, McGraw-Hill, New York, New York.

Rae, John B. 1960. “The 'Know How' Tradition,” Technology and Culture, Vol. 1, No. 1, p. 139150.

Ranyard, J.C., 1988. "A History of OR and Computing.” Journal.of the Operational. Research. Society. Vol. 39, No. 12, p. 1073-1086.

Ritchie, Sebastian, 1997. Industry and Air Power: The Expansion of British Aircraft Production, 1935-1941: Expansion of British Aircraft Production, 1935-41, Routledge, London, England.

Rosenhead, J., 2009, "Reflections on Fifty Years of Operational Research, The Journal of the Operational Research Society, Vol. 60, Supplement, p. s5-s15. 
Rosenberg, Nathan. (Ed. and Commentator) 1969. The American System of Manufactures. Edinburgh University Press, Edinburgh, Scotland.

Rowlinson, Michael, 1988, "The Early Application of Scientific Management by Cadbury," Business History, Vol. 30, No. 4, p. 377-395

Salvesen, M.E., 1955a. “The Assembly Line Balancing Problem,” Journal of Industrial Engineering, Vol. 6, No. 3, p. 18-25.

Salveson, M. E. 1955b, "The Assembly Line Balancing Problem", Transactions of the ASME, Vol. 77, No. 6, p. 939-947.

Sayles, Leonard R. and Alex Stewart, 1995. "Belated Recognition for Work Flow Entrepreneurs: A Case of Selective Perception and Amnesia in Management Thought." Entrepreneurship: Theory and Practice, Vol. 19, No. 3, p. 7-23.

Schachter, Hindy Lauer, 2010. "The role played by Frederick Taylor in the rise of the academic management fields," Journal of Management History, Vol. 16, No. 4, p. 437-448.

Schlesinger, G. 1949. The factory. Sir Isaac Pitman \& Sons, Ltd., London, England.

Simha, Aditya and David J. Lemak, 2010. "The value of original source readings in management education: The case of Frederick Winslow Taylor," Journal of Management History, Vol. 16, No. 2, p. 233-252.

Singhal, Jaya and Kalyan Singhal, 2007. "Holt, Modigliano, Muth and Simon's work and its role in the renaissance and evolution of operations management," Journal of Operations Management, Vol. 25, No. 2, p. 300-309.

Singhal, Kalyan, Jaya Singhal and Martin K. Starr, 2007. "The domain of production and operations management and the role of Elwood Buffa in its delineation," Journal of Operations Management, Vol. 25, No. 2, p. 310-327.

Skinner, Wickham, 1969. "Manufacturing, the Missing Link in Corporate Strategy," Harvard Business Review, Vol. 42, No. 2, p. 136-145.

Skinner, Wickham, 1973. "After Seven Lean Years: Production and Operations Management 1973," Academy of Management Proceedings, p. 556-563.

Skinner, Wickham. 1985. "The Taming of Lions: How Manufacturing Leadership Evolved, 1780-1984”, in Kim b. Clark, Robert H. Hayes \& Christopher Lorenz (ed.), The Uneasy Alliance: Managing the Productivity-Technology Dilemma, Harvard Business School Press, Boston, Mass., p. 63-114.

Skinner, Wickham, 2007. "Manufacturing strategy: the story of its evolution," Journal of Operations Management, Vol. 25, No. 2, p. 328-335.

Smith, Adam. 1776 (Reprinted 2008). An Inquiry into the Nature and Causes of the Wealth of Nations: A Selected Edition, Kathryn Sutherland (Ed), Oxford Paperbacks, Oxford, England.

Smith, Ian and Trevor Boyns, 2005, "Scientific management and the pursuit of control in Britain to c.1960," Accounting, Business \& Financial History, Vol. 15, No. 2, p. 187-216.

Sodhi, Man Mohan and Christopher S. Tang, 2008. "The OR/MS Ecosystem: Strengths, Weaknesses, Opportunities and Threats," Operations Research, Vol. 56, No. 2, p. 267-277. 
Sprague, Linda, 2007. "Evolution in the field of Operations Management," Journal of Operations Management, Vol. 25, No. 2, p. 219-238.

Starr, Martin K., 1996, Operations Management: A Systems Approach, Boyd and Fraser, San Francisco, Ca.

Sterling, F. W., 1914. "The successful operation of a system of Scientific Management," in Thompson, C. B. (ed.) Scientific Management: A collection of the more significant articles Describing the Taylor System of Management, Harvard University Press, Cambridge, Mass, p. 296-365.

Swidler, Ann and Yorge Arditi. 1994. "The New Sociology of Knowledge," Annual Review of Sociology, Vol. 20, p. 305-29

Taylor, F. W., 1903. "Shop Management,” ASME Transactions, Vol. 24, p. 1337-1480.

Taylor, F. W. 1911. Shop Management, Harper \& Brothers Publishers, New York, New York.

Thompson, C. B. (ed.) 1914. Scientific Management: A collection of the more significant articles describing the Taylor system of management, Cambridge, Mass.: Harvard University Press.

Thompson, C. B. 1917. The Taylor system of Scientific Management, A. W. Shaw Co., Chicago, Ill.

Tiratsoo, Nick and Jim Tomlinson, 1993. Industrial efficiency and state intervention: Labour, 1939-51, Routledge/LSE, London, England.

Tiratsoo, Nick, 2004. “The 'Americanization' of Management Education in Britain," Journal of Management Inquiry, Vol. 13, No. 2, p. 118-126.

Tiratsoo, Nick and Jim Tomlinson, 1997. "Exporting the 'Gospel of Productivity': United States Technical Assistance and British Industry 1945-1960,” The Business History Review, Vol. 71, No. 1, p. 41-81.

Tiratsoo, Nick, Edwards, R., \& Wilson, J., 2003. "Shaping the content of business education in Great Britain, 1945-90: production engineers, accountants and shifting definitions of "Relevance"”. In R. P. Amdam, R. Kvalshaugen, \& E. Larsen (Eds.), Inside The Business Schools: The content of European Business Education. Copenhagen Business School Press, Copenhagen, Denmark, p. 178-193.

Tolliday, Steven and Jonathan Zeitlin, (eds.) 1991. The power to manage?: employers and industrial relations in comparative-historical perspective, Routledge, London, England.

Tosdal, H. R., 1932-3. "Hand-to-mouth buying," Harvard Business Review, Vol. 11, p. 299-306.

Towne, Henry R. 1886. The Engineer as Economist, Transactions of the ASME, Vol. 7, p. 428432.

Unattributed, 1970, The Practice of $O \& M$, HMSO, London, England.

Unattributed, 2013. A Guide to the Project Management Body of Knowledge, 5th Edition, Project Management Institute, Newtown Square, Pa.

Ure, Andrew. 1835. The Philosophy of Manufactures, Charles Knight, London, England.

Ure, Andrew. 1840. Dictionary of Arts, Manufactures and Mines, Longman, Orme, Brown, Green and Longman, London, England. 
Voss, C. A., 1984. "Production/Operations Management - A Key Discipline and Area for Research” Omega, Vol. 12, No. 3, p. 309-319.

Wagner-Tsukamoto, Sigmund, 2008. "Scientific Management revisited: Did Taylorism fail because of too positive image of human nature?" Journal of Management History, Vol. 14, No. 4. p. 348-372.

Webster, William A.R., 1973, Handbook of Organization and Methods Analysis, Business Books, London, England.

Whitin, T. M., 1953. The theory of inventory management, Princeton University Press, Princeton, N.J.

Wilson, James M., 1995. “An historical perspective on operations management," Production and Inventory Management Journal, Vol. 35, No. 3, p. 60

Wilson, James M. 1996. "Henry Ford: A Just in Time Pioneer," Production \& Inventory Management Journal, Vol. 37, No. 2, p. 26-31.

Wilson, James M., 2003. "Gantt charts: A centenary appreciation," European Journal of Operational Research, Vol. 149, No. 2, p. 430-437.

Wilson, James M., and Alan McKinlay, 2010. "Rethinking the assembly line: organization, performance and productivity in Ford Motor Company, c. 1908-1927," Business History, Vol. 52, No. 5, p. 760-778.

Wilson, James M., 2014. "Flexible Fordism: Henry Ford vs Assembly Line Balancing," International Journal of Production Research. Vol. 52, No. 3, p. 757-765.

Wilson, James M., 2015. “The Origins of Materials Requirements Planning in Frederick W. Taylor's Shop Management,” International Journal of Production Research. Vol. 52, No. 3, p. 757-765.

Whitston, Kevin, 1997. "The Reception of Scientific Management by British Engineers, 18901914," The Business History Review, Vol. 71, No. 2, p. 207-229.

Whitston, Kevin, 1996. "Scientific Management and Production Management Practice in Britain between the Wars," Historical Studies in Industrial Relations, Vol. 1, No. 1, p. 47-96.

Whitston, Kevin, 2015, "The Ideologies of Practical Men: Trade Unions and the Politics of Public Ownership," Contemporary British History, Vol. 29, No. 1, p. 84-105.

Woolf, Virginia. 1924, David Bradshaw (ed.) 2008. Mr Bennett and Mrs Brown. Selected Essays. Oxford University Press. p. 32-37.

Woollard, F.G. 1925. "Some notes on British methods of continuous production," Proceedings of The Institution of Automobile Engineers, Session 1924-1925, Vol. XIX, The Institution of Automobile Engineers, London, p. 419-474, 885-890, and Plates XVI to XXXII (Figures 126).

Woollard, F.G. 1954. Principles of Mass and Flow Production, Iliffe \& Sons, London, England. 
Figure 1

Time-Line of Production Methods \& Management

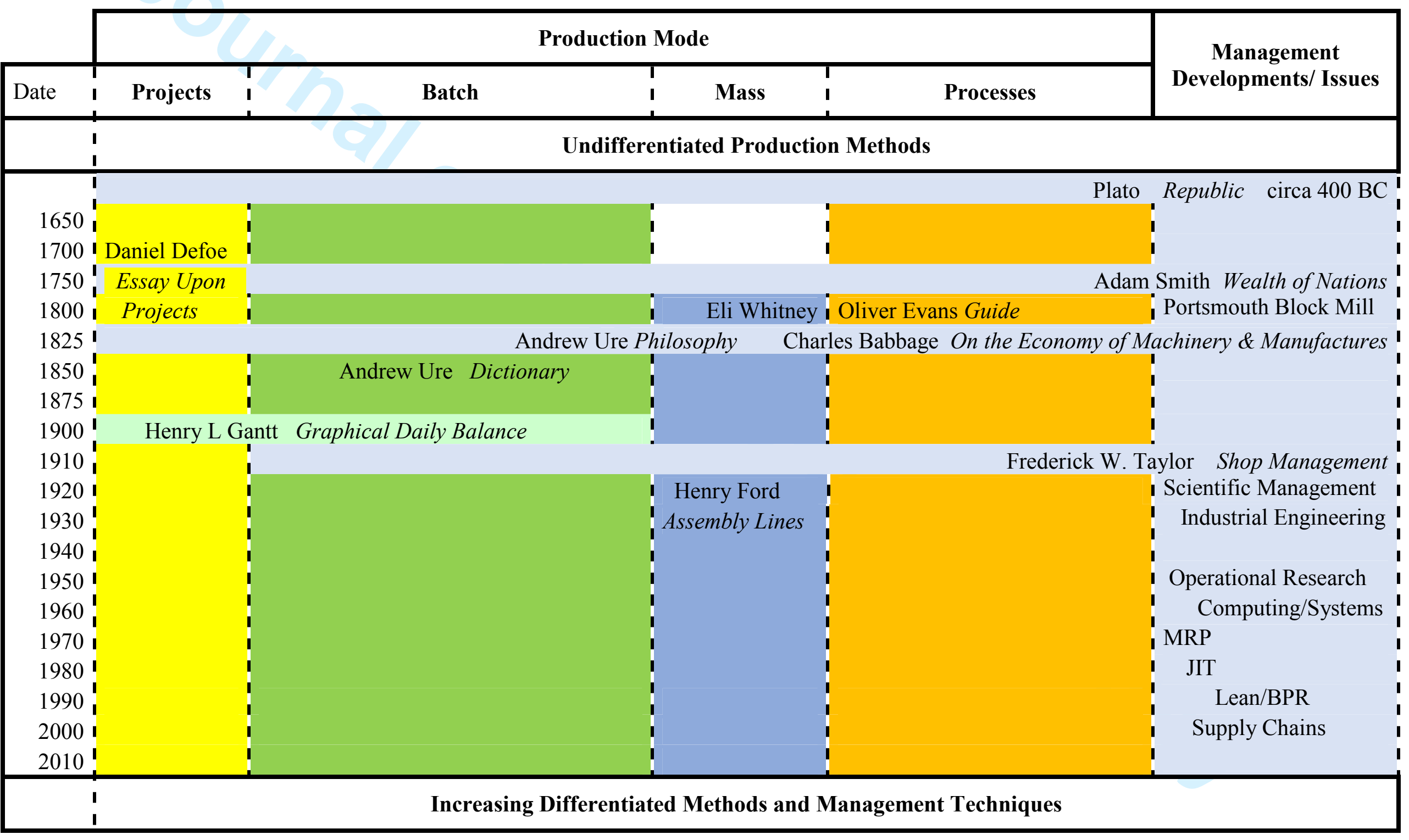




\section{Figure 1}

Time Phased Demand under Scientific Management Knoeppel (1920, Figure 109)

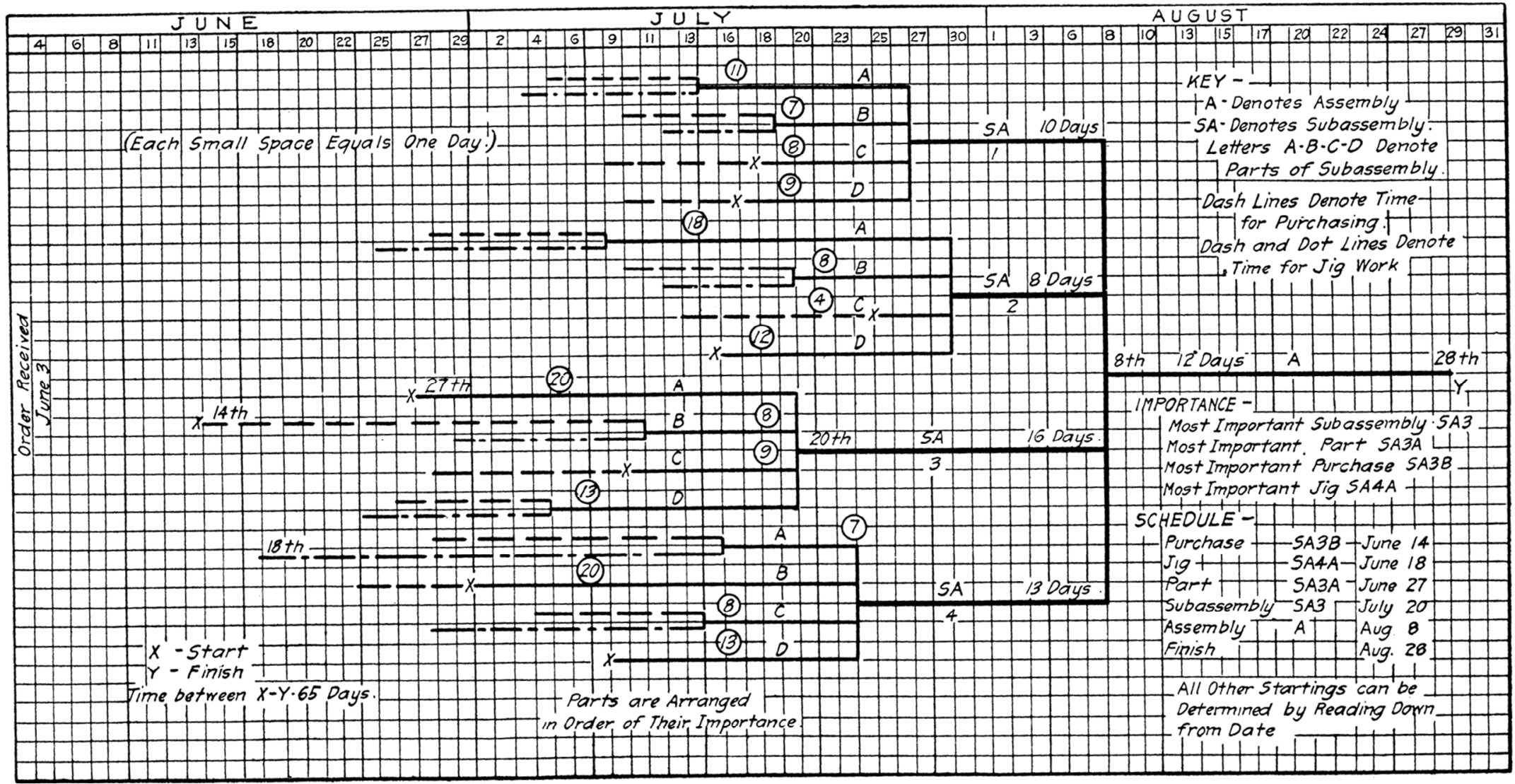

Figure 109. The Ideal Manufacturing Schedule 


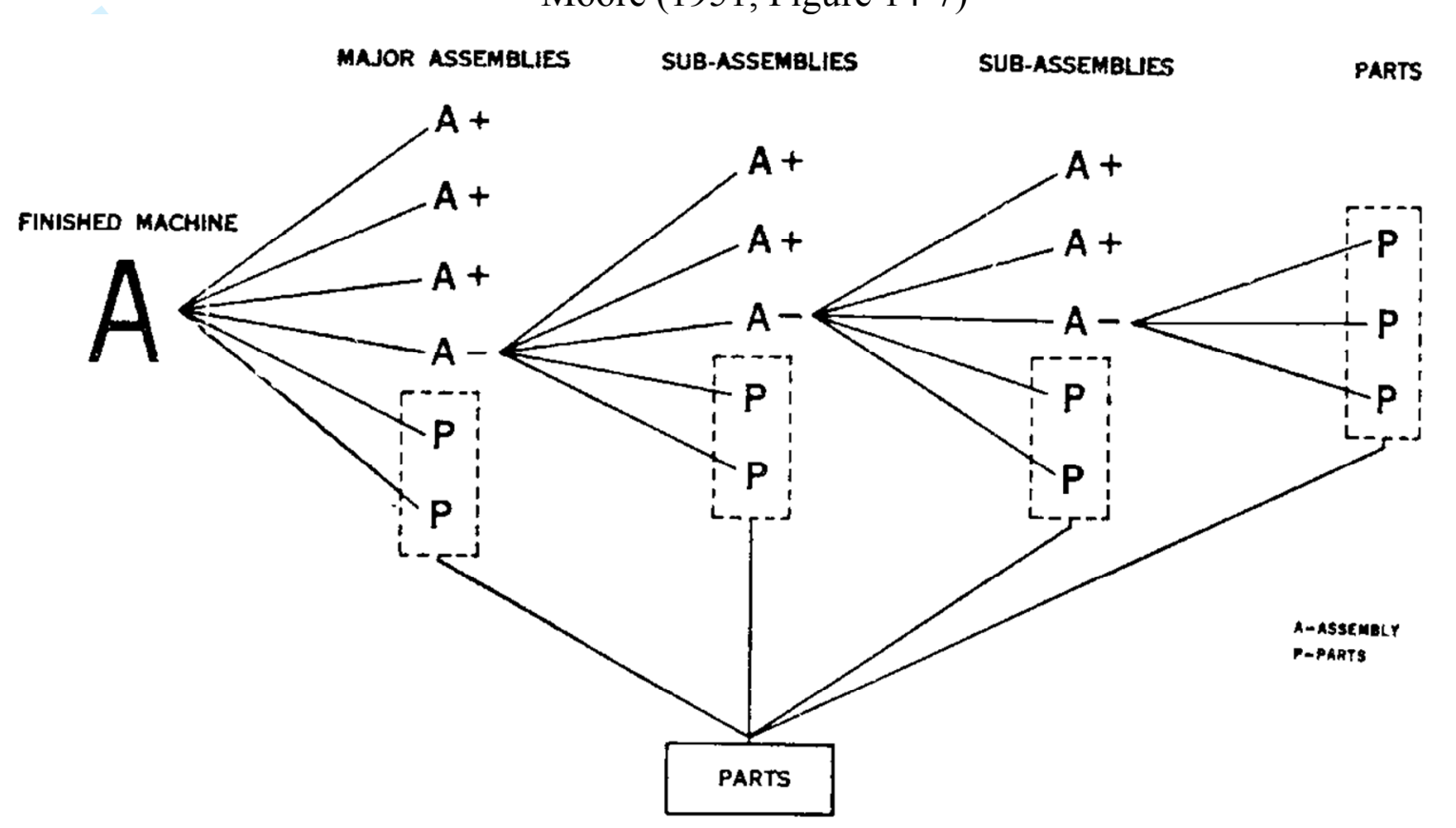

Figure 2

Level-by-Level BOM “explosion”

Moore (1951, Figure 14-7)

Fir. 14-7. A diagram of the "explosion" process as done on tabulating equipment. Starting with a card for product A, the card selecting equipment selects the subasscmbly cards and parts cards for all major subassemblies and all parts going directly into the finished product. The machine automatically prepares requirements cards for the subassemblies and parts needed. The parts cards are temporarily set aside while the subassemblics requirements are compared to their stocks on hand. (In the diagram above, "A+" indicates a sufficient supply of that subassembly, "A-" indicates an insufficient stock.) Where adequate supplies are available, the assemblies are reserved for the order.

For each kind of subassembly not in stock in adequate quantities, manufacturing orders will have to be made up, but not at this point. For each such major subassembly, its minor subassembly requirements and parts requirements must be determined. This is done in exactly the same way as for major subassemblies, namely, by having the equipment selector separate out all cards for the minor subassemblies needed and parts needed which enter directly into the assembly as parts. Again the parts requirements cards are temporarily set aside while minor subassembly requirements are compared to their stocks on hand.

Should any minor subassemblies of which supplies are inadequate be in turn made from lesser subassemblies, the above process is carried through again. Finally all requirements are reduced to parts requirements. Then all parts requirements cards, including those set aside earlier, are brought together and the totals for each determined mechanically. Their requirements are compared to the stocks of parts on hand, and manufacturing orders are originated for all items whose stock is inadequate. (International Business Macbines Corp.) 
Figure 3

Production Planning Tableau circa 1948

Koepke (1949, 1954, p. 391; 1961, p. 151)

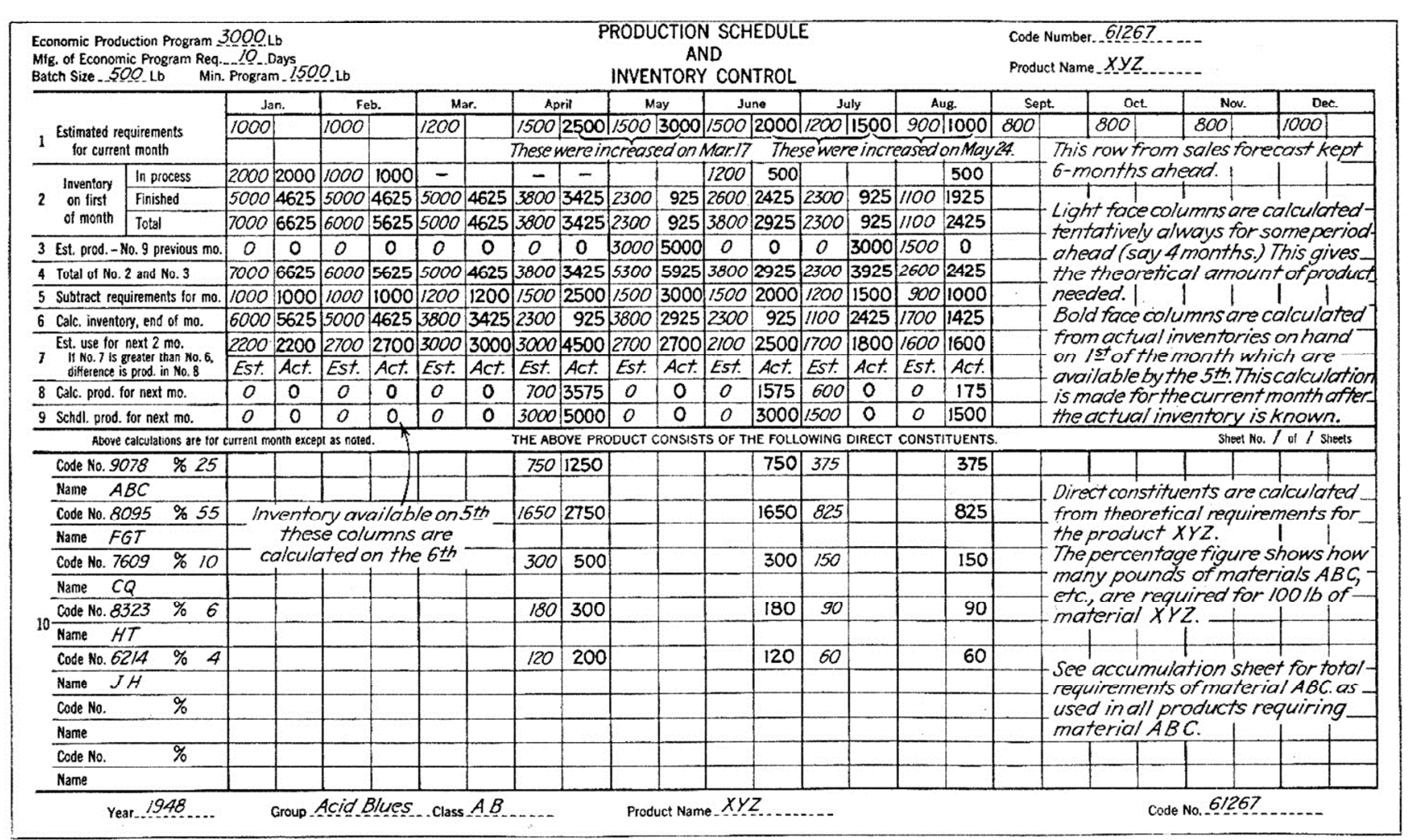

Figure 7. A method for controlling production in a process industry. 


\section{Figure 4}

Production Planning and Control System circa 1949 Moore (1951)

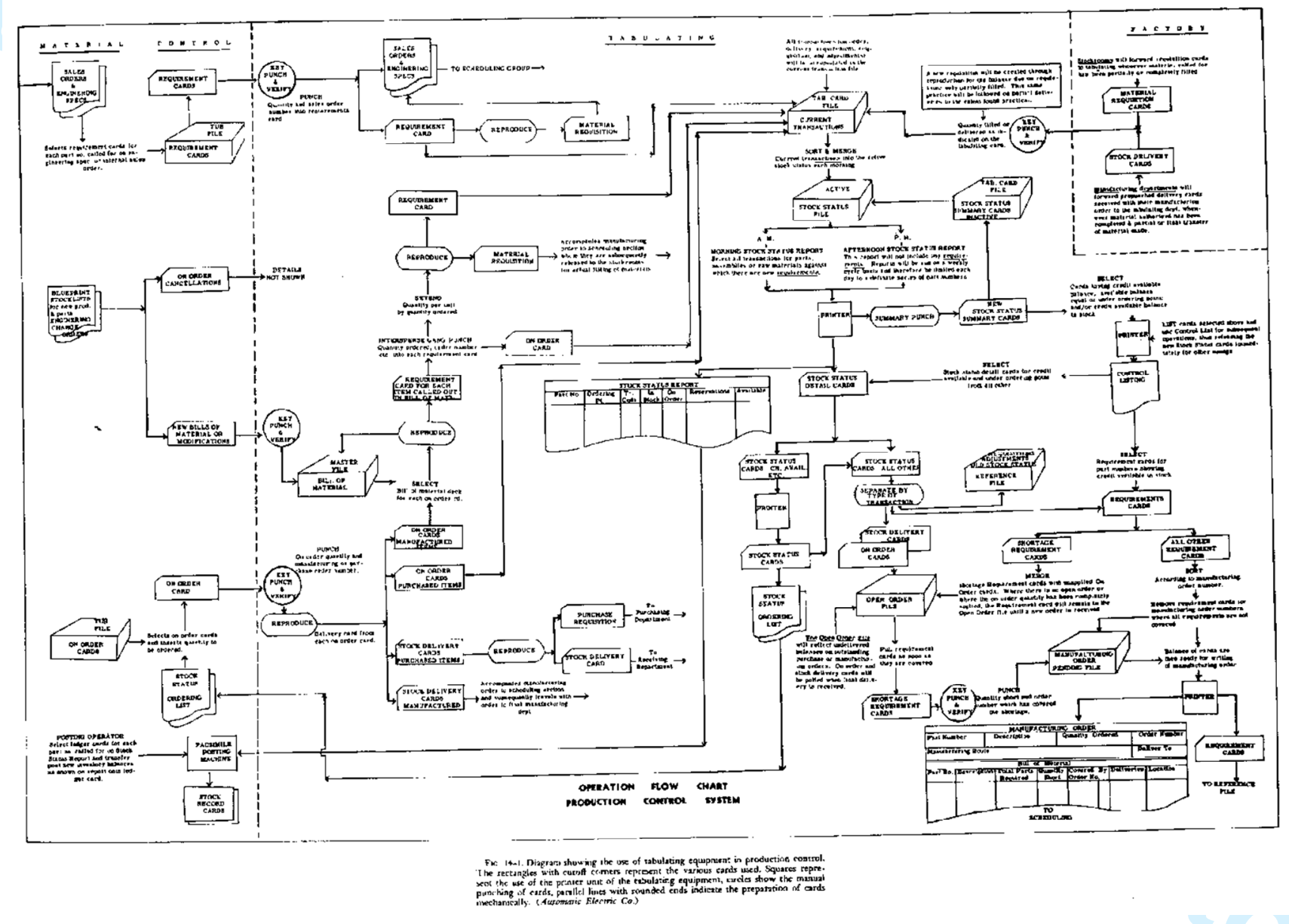


Figure 5

Ford Flexible Assembly Line Production 1913-1915

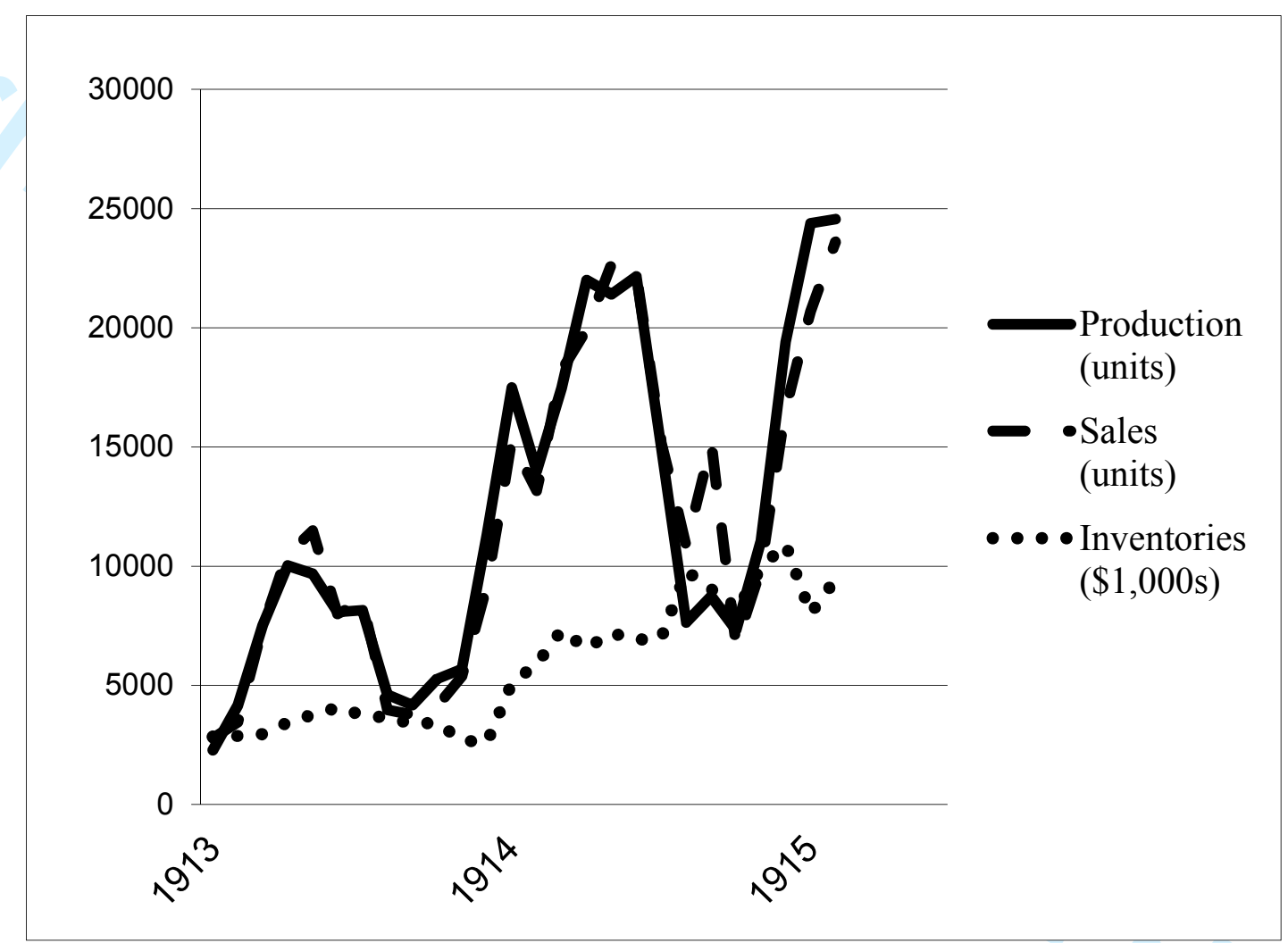

